\author{
mgr Angelika ANDRZEJCZYK \\ Wydział Ekonomii i Zarządzania, Uniwersytet w Białymstoku \\ e-mail: angelika.andrzejczyk@gmail.com
}

DOI: $10.15290 /$ ose.2016.06.84.11

\title{
PRZEDSIĘBIORCZOŚĆ STUDENTÓW WOJEWÓDZTWA PODLASKIEGO ${ }^{1}$
}

\begin{abstract}
Streszczenie
W badaniu zaprezentowano wyniki badań w zakresie przedsiębiorczości młodzieży akademickiej województwa podlaskiego. Głównym celem badań było określenie zależności zachodzacych pomiędzy stopniem, trybem i rokiem kształcenia a przejawiana przedsiębiorczością. Postawy przedsiębiorcze identyfikowano za pomoca cech osobowości sygnalizowanych przez studentów, a także działań podejmowanych przez studentów, takich jak założenie własnej działalności gospodarczej czy też sama chęć założenia własnej działalności gospodarczej.

Badanie postaw przedsiębiorczych na podlaskich uczelniach zostało przeprowadzone w 2015 roku wśród 2004 studentów. W doborze próby zastosowano dobór losowy warstwowy, a w badaniu wykorzystano kwestionariusz ankiety skonstruowany specjalnie na potrzeby tego badania. Podjęte przez autorkę badania są wyrazem zainteresowania tematyką przedsiębiorczości, a przedstawione wyniki powinny stanowić zachętę do podejmowania dalszych badań dotyczących przedsiębiorczości.
\end{abstract}

Słowa kluczowe: przedsiębiorczość, postawa

\section{ENTREPRENEURSHIP OF STUDENTS IN PODLASKIE VOIVODESHIP}

\section{Summary}

The aim of the study was to evaluate the entrepreneurial attitudes of the students of Podlaskie Voivodeship and to identify the correlation between the study cycle, degree and course type and manifested entrepreneurial attitudes. Entrepreneurial attitudes were identified by means of the students' personality traits, as well as through activities undertaken by them, such as starting their own business, or the intention to do so.

The study of entrepreneurial attitudes at Podlaskie's higher education institutions was conducted in 2015 among 2,004 students. The sampling of the population group was random and stratified; the questionnaire had been designed specifically for the needs of the study. Research undertaken by the author is an expression of a deep interest in the subject of entrepreneurship and the results presented in the paper should encourage further studies in the field.

Key words: entrepreneurship, attitude

JEL: C1, J230, J240, L260

\footnotetext{
${ }^{1}$ Praca naukowa finansowana ze środków budżetowych na naukę w latach 2014-2016 jako projekt badawczy w ramach programu pod nazwa „,Diamentowy Grant”.
} 


\section{Wstęp}

Przedsiębiorczość to szeroka kategoria zjawisk obejmująca: postawy, zachowania i wartości w życiu człowieka. Jednocześnie należy zauważyć, iż obecnie postrzeganie przedsiębiorczości coraz częściej odnosi się do nowych aktywności ludzkich wymagających inicjatywy, a nie jedynie do samej działalności gospodarczej.

Przedsiębiorczość stanowi podstawowy czynnik wzrostu aktywności gospodarczej w każdym kraju, jednakże by można było mówić o przedsiębiorczości, niezbędne są zarówno inicjatywy jednostek przejawiających postawy przedsiębiorcze, jak i odpowiednie rozwiązania systemowe, w tym edukacyjne [Grzegorzewska-Mischka, Wyrzykowski, 2009].

Działania przedsiębiorcze podejmowane przez ludzi wywierają wpływ na utworzenie swoistej kultury ekonomicznej w społeczeństwie. Działając na rzecz rozwoju przedsiębiorczości, warto zatem nie tylko promować zakładanie własnej działalności, ale także motywować do zwiększonego wysiłku w doskonaleniu siebie i dążeniu do rozwoju osobistego, tak aby wytworzyć kulturę przedsiębiorczości. Stosując odpowiednie, przemyślane działania, można więc zachęcić młodzież do lepszego przygotowania do samodzielności i uwrażliwić ją na wykorzystywanie nadarzających się szans.

Wizja wzrostu aktywności przedsiębiorczej, czy to w wymiarze działalności gospodarczej, czy działań na tle społecznym bądź prorozwojowym, jest przedmiotem licznych analiz naukowych zajmujących się współzależnościami między takimi determinantami, jak np.: edukacja, wychowanie, kultura a kształtowaniem się na tym tle: opinii, postaw, wartości, zachowań i działań podejmowanych przez jednostki lub grupy.

W przeprowadzonym badaniu przedsiębiorczość nie została ograniczona jedynie do rejestracji nowej działalności gospodarczej, a poszerzono ją również o zachowania związane z podejmowaniem aktywności zawodowej i dążeniem do doskonalenia jednostki, lecz ze względu na szeroki zakres badań prowadzonych przez autorkę, w niniejszym artykule przytoczono tylko część wyników dotyczących postaw przedsiębiorczych młodzieży akademickiej.

Przedsiębiorczość to sposób myślenia wykorzystywany równocześnie w codziennym życiu, w domu i w społeczeństwie, dlatego z licznych cech kojarzonych z postawą przedsiębiorczą wybrano do badania te, które, zdaniem autorki, najlepiej oddaja postawę przedsiębiorcza. W niniejszym opracowaniu za cel przyjęto określenie postaw przedsiębiorczych młodzieży akademickiej województwa podlaskiego - identyfikację zależności zachodzacych pomiędzy: stopniem, trybem, rokiem i kierunkiem kształcenia a przejawianą postawą przedsiębiorcza.

\section{Postawa a przedsiębiorczość}

Badania postaw mają długą historię. Przez postawę można rozumieć: trwałą ocenę (zarówno ludzi, idei, jak i obiektów) [Aronson, Wilson, Akert, 1997], reagowanie emocjami i zachowaniem spowodowane postrzeganiem ludzi, idei i obiektów [Rathus, 2004], 
ukierunkowanie danej jednostki powodujące określone zachowanie i reakcje na dostarczane bodźce [Frankfort-Nachmias, Nachmias, 2001], skłonność do reagowania na dane bodźce w określony sposób [Oppenheim, 2004]. Mimo że różni autorzy kładą nacisk na rozmaite aspekty postaw, można stwierdzić, że dostrzegane jest względnie trwałe podejście jednostki przejawiające się konkretnym zachowaniem w danej sytuacji [Czerwiński, 2007].

Na potrzeby pomiaru w opracowaniu postawę potraktowano jako skłonność do reakcji na dane bodźce w określony sposób. Oznacza to, że często przyjmowana postawa, na przykład wobec przedsiębiorczości, uwidacznia się dopiero podczas dyskusji na dany temat lub podejmowanego działania przedsiębiorczego (konfrontacja z wybranym przedmiotem). Postawy ulegaja przy tym wzmocnieniu. Do elementów wzmacniających postawy można zaliczyć przekonania i uczucia rodzące określone skłonności do działania. Co więcej, postawy, poza przekazywaną treścią, wyrażane są z różnorodną intensywnością [Oppenheim, 2004]. Jest to o tyle istotne, że w przypadku postaw przedsiębiorczych stanowią one podstawę do podejmowania przedsięwzięć nie tylko komercyjnych, ale i o charakterze społecznym.

Przedsiębiorczość jest przedmiotem analizy w wielu dziedzinach nauk, głównie w dziedzinie nauk: społecznych, ekonomicznych lub prawych. Rozpatrując pojęcie przedsiębiorczości w polskim ustawodawstwie, przedsiębiorcą określa się osoby fizyczne, prawne i jednostki organizacyjne niebędące osoba prawną, którym ustawa przyznaje zdolność prawną w zakresie zakładania i prowadzenia własnej działalności gospodarczej, a także wspólników spółki cywilnej w zakresie wykonywanej przez nich działalności gospodarczej [Ustawa z dnia 2 lipca..., 2004]. Definicja ta jest wąska i dlatego też na potrzeby badań rozszerzono ją również o zachowania skierowane w stronę podejmowania aktywności zawodowej i dążenia do doskonalenia jednostki.

Jednocześnie przedsiębiorczość to poszukiwanie i wdrażanie nowych form rozwoju przez szczególnie aktywne i mobilne jednostki, a działania przedsiębiorcze często przybierają formę udziału w ważnych wydarzeniach, takich jak emigracje czy podboje terytorialne [Piecuch, 2010]. Osoby przedsiębiorcze wykazuja pewne specyficzne cechy osobowości oraz zdolności, w tym zdolność do uczenia się i rozwijania własnej wiedzy [Grzegorzewska-Mischka, 2010].

W kontekście edukacji zagadnienie przedsiębiorczości można przedstawić za pomocą dwóch, rywalizujących poglądów, a mianowicie: przedsiębiorczość jest wrodzonym zespołem cech oraz cechy przedsiębiorcze można w sobie wykształcić w drodze edukacji [Kokocińska, Nowak, 2014, za: Piecuch, 2010]. Wydaje się, że mimo sprzecznych poglądów, aktualnie wśród badaczy dominuje ten o pozytywnym wpływie edukacji na rozwój przedsiębiorczości. Ponadto, rozwój ten nie jest nastawiony jedynie na zakładanie własnej działalności gospodarczej, bowiem dostrzeżono korzyści płynące z przedsiębiorczej postawy również w codziennym życiu [Kokocińska, Nowak, 2014, za: Brzezińska, Schmidt, 2008].

Działania przedsiębiorcze są związane z nietypowym rozwiązywaniem problemów nie tylko w przypadku prowadzenia działalności gospodarczej, ale także rozwiązywania ogólnych problemów: ekonomicznych, technicznych, organizacyjnych i pracowniczych 
zarówno w środowisku pracy, jak i w codziennych sytuacjach. Radzenie sobie z problemami wiąże się z podejmowaniem samodzielnych i odpowiedzialnych decyzji uwzględniających całokształt posiadanej wiedzy i umiejętności jednostki. Występuje przy tym pewien stopień niepewności i ryzyka co do powodzenia założonego celu, dlatego też istotne jest, aby minimalizować ryzyko poprzez jakość i ilość dostępnych oraz posiadanych informacji [Haber, 2011].

Przedsiębiorcy charakteryzują się wieloma cennymi cechami, które można wykształcać w drodze edukacji. Jedną z szeroko opisywanych w literaturze cech jest skłonność do ryzyka (już od okresu J. Schumptera jest to kwestia często poruszana). Jednak ryzyko nieodzownie łączy się z odpowiedzialnością za podjęte działania, a gdy pojawią się problemy, ważną cechą jest traktowanie ich jako wyzwań, co może „stresującą” sytuację przekształcić w korzyść. Kluczowe jest zarazem opanowanie w trudnych sytuacjach, które pozwala na zachowanie zdrowego rozsądku nawet w najbardziej wymagającej sytuacji. Warto również zwrócić uwage na brak obaw przed nietypowymi rozwiązaniami u przedsiębiorców, które może przyczynić się do zastosowania innowacyjnych rozwiązań.

Założenie własnej działalności gospodarczej czy zaprojektowanie ciekawej inicjatywy społecznej wiąże się z posiadaniem wielu pomysłów, które można następnie wcielić w życie. Jednakże, wyznaczając sobie konkretny cel do realizacji, należy cechować się wytrwałością związaną z wytężoną praca, tak aby osiagnąć postawiony cel. Pomocne może być równocześnie podejmowanie działań w zakresie rozwoju osobistego - będąc na bieżąco z wiedzą i umiejętnościami, jednostka nie zostanie wyprzedzona w swojej dziedzinie bądź zainteresowaniach.

Same cechy charakteru mogą być niewystarczające w czasie prowadzenia własnej działalności - istotne są także zdobyte umiejętności. Przedsiębiorcy nie mogą funkcjonować bez kontaktów z otoczeniem, w tym z klientami. Implikuje to konieczność nabywania umiejętności nawiązywania kontaktów z innymi ludźmi. Łatwość (umiejętność) nawiązywania kontaktów z ludźmi otwiera perspektywę prowadzenia własnej działalności gospodarczej. Zdobyte przez potencjalnego przedsiębiorcę umiejętności organizacyjne również wpływają na funkcjonowanie podejmowanych przez niego przedsięwzięć, zaś kojarzenie różnorodnych informacji pozwala na łatwe dostosowywanie się do zmian zachodzących w otoczeniu osoby przedsiębiorczej.

Przedstawione cechy i umiejętności posłużyły stworzeniu trzynastu stwierdzeń dotyczących cech osobowości utożsamianych przez badacza z cechami osób przedsiębiorczych. Skonstruowane na potrzeby badań stwierdzenia związane z przejawiana postawą przedsiębiorcza pomogły w określeniu nasilenia poszczególnych cech przedsiębiorczych oraz zależności występujących pomiędzy przejawianą postawą a edukacją studentów.

\section{Przedsiębiorczość w wybranych badaniach naukowych}

Różne aspekty przedsiębiorczości są badane przez naukowców z całego świata (C. Howieson, J. McKechnie, L. Brownlow, M. L. Harris, Sh. G. Gibson, Sh. Semple, 
T. D. Mick, T. M. Burkhalter i wielu innych). Zarówno sami badacze, jak i instytucje naukowo-badawcze poświęcają czas i środki finansowe na próby odkrycia zależności występujących między różnymi zmiennymi a rozwojem przedsiębiorczości. Postawy przedsiębiorcze i efekty działań przedsiębiorców istotnie wpływają na rozwój gospodarczy i osiaganie przewagi konkurencyjnej, co przekłada się na rosnące zainteresowanie tematem przedsiębiorczości.

Naukowcy z Wielkiej Brytanii podjęli się przeglądu istniejących metod pomiaru umiejętności i postaw przedsiębiorczych [Brownlow, Semple, Howieson, McKechnie, 2004]. Za cel przyjęto zidentyfikowanie definicji umiejętności i postaw przedsiębiorczych, a także wykorzystanie zebranej wiedzy we własnych badaniach. Badania prowadzono na podstawie ogólnodostępnych danych zebranych w Wielkiej Brytanii oraz poza jej granicami, jak również dwóch niepublikowanych projektów: Research into the Educational and Economic Benefits of Enterprise Education oraz Research into the definitione of an Enterprising School. Jednym z wniosków dokonanego przeglądu było stwierdzenie trudności w znalezieniu miar przedsiębiorczości i postaw odpowiednich do prowadzenia dalszych badań. Za powód trudności uznano ograniczoną dostępność miar poświęconych przedsiębiorczości [Brownlow, Semple, Howieson, McKechnie, 2004].

Badania prowadzone w USA na grupie 395 studentów w amerykańskich, dwuletnich uczelniach (Community colleges) $(\mathrm{N}=220)$ oraz uczelniach czteroletnich $(\mathrm{N}=175)$ wykazały, że studenci studiów czteroletnich wyróżniaja się postawami przedsiębiorczymi silniejszymi od rówieśników z Community College [Gibson, Harris, Mick, Burkhalter, 2011]. W badaniu wykorzystano ankietę Entrepreneurial Attitudes Orientation (EAO), bazująca na: osiagnięciach, innowacjach, kontroli osobistej i poczuciu własnej wartości. W badaniu stwierdzono, że studenci uczelni czteroletnich czują się znacznie lepiej przygotowani do zakładania własnych firm niż studenci po dwuletnich uczelniach. Jednym z wniosków był ten, że skuteczne programy edukacyjne wymagają użycia wielu narzędzi i strategii uczenia się. Ważne jest także uwzględnianie w badaniach przedsiębiorczości studentów różnych typów uczelni i kierunków studiów podejmowanych przez młodzież akademicką. Ich lepsza znajomość może istotnie wpłynąć na opracowanie skutecznych programów nauczania przedsiębiorczości. Jednocześnie warto badać skuteczność różnych programów edukacji przedsiębiorczości stosowanych w rozmaitych placówkach oświatowych [Gibson, Harris, Mick, Burkhalter, 2011].

Według Raportu o stanie sektora malych i średnich przedsiebiorstw w Polsce w latach 2011-2012, w latach 2010-2012 Polska przewyższyła unijną średnią w udziale osób prowadzących firmę (18\% w Polsce) przy średniej dla Unii Europejskiej na poziomie 14\%. Za przedsiębiorcę uznano człowieka powyżej 15. roku życia prowadzącego działalność gospodarczą. W raporcie również zwrócono uwagę na wykształcenie pracodawców, którzy pod względem wykształcenia uplasowali się powyżej średniej Unii Europejskiej [Węcławska, 2013]. Stwierdzono, że wyższe wykształcenie wiąże się z wyższym kapitałem kulturowym, a w konsekwencji przedsiębiorcy, którzy posiadają wyższy kapitał kulturowy, są właścicielami najbardziej ekspansywnych przedsiębiorstw [Węcławska, 2013, za: Plawgo, Kornecki, 2010]. Warto równocześnie wspomnieć o udziale kobiet (32\%) w grupie przedsiębiorców, który jest znacznie niższy niż mężczyzn (68\%). Mimo że udział kobiet systematycznie rośnie, to jeszcze nadal jest niższy od ich rzeczywistego 
potencjału (mierzonego udziałem kobiet w populacji czy też udziałem wśród osób w wieku produkcyjnym). Przy tym, 23\% kobiet posiada dyplom szkoły wyższej, a w przypadku mężczyzn taki dyplom ma tylko $14 \%$ z nich [Węcławska, 2013].

W jednym $z$ analizowanych badań A. Gaweł i M. Pietrzykowski skupili się na postrzeganiu przedsiębiorczości i intencjach przedsiębiorczych [Gaweł, Pietrzykowski, 2015]. Przyjęto hipotezy, że edukacja przedsiębiorcza ma pozytywny wpływ na kształtowanie postrzegania przedsiębiorczości i kształtowanie intencji przedsiębiorczych. Badaniu poddano studentów dziennych studiów magisterskich Uniwersytetu Ekonomicznego w Poznaniu, uczestniczących $\mathrm{w}$ zajęciach $\mathrm{z}$ przedmiotu przedsiębiorczość międzynarodowa (zarówno w ćwiczeniach, jak i w wykładzie). Podczas realizacji tych zajęć studenci brali udział w eksperymentalnych metodach dydaktycznych, opartych na grze symulacyjnej i własnym projekcie nowego przedsiębiorstwa, które miały za zadanie rozwinąc u nich zdolności przedsiębiorcze. Na początku i na końcu realizacji zajęć przeprowadzono wśród studentów ankietę, w której respondenci określali sposób postrzegania przedsiębiorczości oraz swoje intencje przedsiębiorcze. Hipotezy zweryfikowano na podstawie porównania ocen dokonanych w ankietach z początku i z końca zajęć. Okazało się, że studenci pozytywnie postrzegali przedsiębiorczość, a także wykazywali relatywnie wysoki poziom intencji przedsiębiorczych, zaś zastosowane metody dydaktyczne w ramach edukacji przedsiębiorczej poprawiły oceny studentów w tych obszarach [Gaweł, Pietrzykowski, 2015]. Interesujących badań intencji przedsiębiorczych młodzieży akademickiej kierunków nieekonomicznych podjęli się również T. Rachwał i K. Wach [Rachwał, Wach, 2016].

Według Raportu o stanie sektora MSP w Polsce w latach 2008-2009, w którym przeanalizowano m.in. ponad 90 opracowań międzynarodowych dotyczących m.in. związków pomiędzy wykształceniem a przedsiębiorczościa, nie ma jednoznacznie pozytywnego wpływu edukacji na wzrost liczby przedsiębiorstw [Węcławska, Zadura-Lichota, 2010, za: van der Sluis, van Praag, Vijverberg, 2003]. Z drugiej strony zaobserwowano pozytywny wpływ edukacji na sposób prowadzenia firm. Zasadniczym wnioskiem z badań jest to, że wszystkie opracowania objęte analizą były w jakiś sposób stronnicze. Na trudności w porównywaniu wyników badań oddziałuje to, że różni badacze stosuja rozmaite miary przedsiębiorczości, edukacji oraz skuteczności funkcjonowania przedsiębiorstw. W związku z tym, to właśnie brak jednolitej metodologii badawczej wydaje się być znacząca przeszkodą w powstaniu jednoznacznie skwantyfikowanej wiedzy na temat potencjalnego wpływu edukacji na przedsiębiorczość [Węcławska, Zadura-Lichota, 2010] i postawy przedsiębiorcze.

Mimo że sa prowadzone badania dotyczące przedsiębiorczości, postaw przedsiębiorczych, a także przedsiębiorczości w kontekście edukacji, nadal temat ten jest niewyczerpany. Istotę kształtowania postaw przedsiębiorczych w społeczeństwie coraz częściej dostrzegają nie tylko naukowcy, władze państwowe na całym świecie czy instytucje międzynarodowe, ale i obywatele, w tym studenci, którzy czynnie biorą udział w różnych prorozwojowych wydarzeniach organizowanych chociażby przez uczelnie, do których uczęszczaja. Instytucje, takie jak OECD czy Komisja Europejska starają się motywować do zwiększonego wysiłku w zakresie rozwijania postaw przedsiębiorczych spoleczeństw z wykorzystaniem edukacji przedsiębiorczej. Szczególne zainteresowanie różnych 
podmiotów przedsiębiorczością i kształtowaniem postaw przedsiębiorczych, zwłaszcza wśród ludzi młodych, może w przyszłości skutkować zmianami w systemie edukacyjnym.

\section{Metodyka badań}

Badanie postaw przedsiębiorczych zostało przeprowadzone w 2015 roku wśród 2004 studentów na podlaskich uczelniach wyższych. W doborze próby zastosowano dobór losowy warstwowy, a w badaniu wykorzystano kwestionariusz ankiety skonstruowany specjalnie na potrzeby tego badania. Za cechy warstwujące przyjęto: poziom kształcenia (studia pierwszego, drugiego stopnia oraz jednolite magisterskie), formę studiów (stacjonarne, niestacjonarne), rodzaj uczelni (publiczne, niepubliczne), poszczególne 16 uczelni i wszystkie 81 kierunki studiów funkcjonujące w semestrze letnim 20152016 roku akademickiego pogrupowane w 8 grup kierunków wzorowanych na metodologii Głównego Urzędu Statystycznego. Próbę wyznaczono na podstawie danych pozyskanych z Ministerstwa Nauki i Szkolnictwa Wyższego w odniesieniu do liczby studentów na poszczególnych podlaskich uczelniach, w tym: stopniach studiów, kierunkach studiów, trybach studiów. Minimalną liczebność próby wyznaczono na podstawie wzoru $n \geq \frac{u_{a}^{2}}{4 d^{2}}$, przy założonym trzyprocentowym maksymalnym błędzie szacunku i jednoprocentowym poziomie istotności:

$$
u_{0,01}=2,5758 \quad n \geq \frac{2,5758^{2}}{4 \cdot 0,03^{2}} \quad n \geq 1843 .
$$

Przy powyższych założeniach minimalna liczebność próby wynosiła 1843 studentów. W związku z dofinansowaniem projektu naukowego przez Ministerstwo Nauki i Szkolnictwa Wyższego, w którym określono, że badanie zostanie przeprowadzona na próbie 2 tys. studentów, badaniu poddano 2004 osoby.

W badaniu udział wzięło 63,8\% kobiet i 36,2\% mężczyzn. Natomiast $85,9 \%$ respondentów studiowało na uczelniach publicznych, $14,1 \%$ na uczelniach prywatnych, $66,5 \%$ studentów studiowało w trybie stacjonarnym (dziennym), a 33,5\% w trybie niestacjonarnym (zaocznym).

Rozkład badanej próby w podziale na stopnie studiów respondentów kształtował się następująco: 65,5\% ankietowanych studiowało na pierwszym stopniu studiów (studia licencjackie, inżynierskie), 22,4\% studiowało na stopniu drugim (magisterskim), a 12,1\% studentów kształciło się na studiach jednolitych magisterskich. W przypadku studiów pierwszego stopnia 22,3\% studentów tych studiów było na pierwszym roku studiów, $40,5 \%$ było na drugim roku, a $37,2 \%$ na trzecim roku studiów. Wśród studentów studiów drugiego stopnia $65 \%$ stanowili studenci pierwszego roku studiów, a $35 \%$ drugiego roku studiów. Natomiast rozkład udziału studentów studiów jednolitych magisterskich, biorących udział w badaniu, kształtował się w następujący sposób: $37,9 \%$ było na pierwszym roku studiów, 5,8\% na drugim roku, $37,9 \%$ na trzecim roku, $12,3 \%$ na czwartym roku, a 6,2\% na piątym roku studiów. 
Pytania zawarte w kwestionariuszu skoncentrowano na tym, czy respondent wykazuje postawę przedsiębiorczą i w jakim stopniu, czy prowadzi lub prowadził działalność gospodarczą lub wykazuje chęć założenia własnej działalności, a w kontekście dobranej próby badawczej, czy uczestnictwo w kształceniu na poziomie studiów wyższych ma związek z przyjmowana postawą przedsiębiorczą.

Pierwsze pytanie obejmowało trzynaście stwierdzeń dotyczących cech osobowości utożsamianych przez badacza z cechami osób przedsiębiorczych. Skonstruowane na potrzeby badań stwierdzenia związane z przejawianą postawa przedsiębiorczą pomagały w identyfikacji nasilenia u studentów poszczególnych cech przedsiębiorczych oraz zależności występujących pomiędzy przejawianą postawą a stopniem, trybem, rokiem i kierunkiem kształcenia studentów. Stwierdzenia, określające przejawiane postawy przedsiębiorcze, to:

1. Latwo nawiązuję kontakt $\mathrm{z}$ innymi ludźmi.

2. Nie boję się nietypowych rozwiązań.

3. Umiem brać odpowiedzialność za podejmowane działania.

4. Posiadam umiejętności organizacyjne.

5. Pojawiające się problemy traktuję jako wyzwania.

6. Chętnie angażuję się w nowe przedsięwzięcia.

7. Lubię przejmować inicjatywę $\mathrm{w}$ realizowanych przedsięwzięciach.

8. Latwo dostosowuję się do zmian zachodzących w moim otoczeniu.

9. Posiadam wiele pomysłów, które chciałabym/chciałbym zrealizować.

10. Kiedy wyznaczę sobie jakiś cel, ciężko pracuję, by go osiągnąć.

11. Podejmuję działania w zakresie rozwoju osobistego.

12. W trudnych sytuacjach jestem opanowana/opanowany.

13. Uważam, że jestem przedsiębiorcza/przedsiębiorczy.

Respondenci, biorący udział w badaniu, mogli ustosunkować się do tych stwierdzeń przez udzielenie do każdego z nich jednej odpowiedzi z zakresu: „zdecydowanie nie”, ,raczej nie”, „raczej tak” i ,zdecydowanie tak”. Odpowiedziom tym przypisano punkty, odpowiednio: ,zdecydowanie nie” - 0, „raczej nie” - 1, „raczej tak” - 2 i ,zdecydowanie tak" - 3. Na tej podstawie zbudowano wskaźnik przedsiębiorczości (WSKP), który bazował na średniej punktacji wyznaczonej w wyniku wszystkich stwierdzeń. Wartość wskaźnika przedsiębiorczości oscylowała zatem w przedziale $<0,3>$. Ocena postaw przedsiębiorczych na podstawie zbudowanego wskaźnika została podzielona na 4 przedziały. Jeżeli wskaźnik zawierał się w przedziale $<0-1$ ) punktu, oznaczało to brak postawy przedsiębiorczej. Przedział <1-2) punktu obejmował niski stopień postawy przedsiębiorczej, zaś przedział <2-2,5) punktu średni stopień postawy przedsiębiorczej. Natomiast liczba punktów, zawierająca się w przedziale $<2,5-3>$ punktów, to wysoki stopień postawy przedsiębiorczej.

Badając postawy przedsiębiorcze młodzieży akademickiej, zapytano również o prowadzenie własnej działalności gospodarczej zarówno aktualnie, jak i w przeszłości, a także o chęć założenia własnej działalności gospodarczej przez respondentów. W pierwszym przypadku odpowiedzi ograniczały się do udzielenia odpowiedzi „tak” i określenia przez ile miesięcy/lat prowadzono działalność (ze względu na ograniczenia objętości tekstu w dalszej analizie nie uwzględniono okresu prowadzenia działalności gospodarczej) 
lub „Nie prowadzę/nie prowadziłem działalności gospodarczej”. W drugim przypadku, oprócz potwierdzenia lub niepotwierdzenia chęci założenia własnej działalności gospodarczej, można było udzielić odpowiedzi ,jeszcze o tym nie myślałem”.

\section{Wskaźnik postaw przedsiębiorczych studentów województwa podlaskiego i prowadzenie własnej działalności gospodarczej - wyniki badań}

Pierwsza część analizy dotyczyła postaw przedsiębiorczych studentów województwa podlaskiego.

Na podstawie zbudowanego wskaźnika ogólnego i wyodrębnionych czterech typów postaw przedsiębiorczych stwierdzono, że brak postawy przedsiębiorczej wykazało $1,7 \%$ z ogółu respondentów, niski stopień postawy przedsiębiorczej 34,03\%, średni stopień postawy przedsiębiorczej 46,81\%, natomiast wysoki stopień postawy przedsiębiorczej 17,46\%. Co więcej, gdy za podstawę podziału przyjąc kwartyle, okazało się, że $25 \%$ studentów przejawiało postawę przedsiębiorczą co najwyżej wynoszącą 1,85, a 75\% co najmniej 1,$85 ; 50 \%$ studentów okazywało postawę przedsiębiorczą co najwyżej wynoszącą 2,08, a 50\% co najmniej 2,08; zaś $75 \%$ studentów objawiało postawę przedsiębiorczą co najwyżej wynosząca 2,39, a 25\% co najmniej 2,39 [Andrzejczyk, 2016].

Ogólna wartość wskaźnika przedsiębiorczości dla badanej grupy wyniosła 2,094, co oznacza, że według przyjętych kryteriów wyodrębniania typów postaw, studenci podlaskich uczelni wykazywali średni stopień postawy przedsiębiorczej. Rozkładając wskaźnik dla całej badanej grupy na poszczególne cechy (od najwyższej uzyskanej średniej liczby punktów do najniższej uzyskanej średniej liczby punktów), można stwierdzić, że studenci w najwyższym stopniu uważali się za odpowiedzialnych za podejmowane działania $(2,55)$. Następnie studenci podejmowali działania w zakresie rozwoju osobistego $(2,37)$ oraz kiedy wyznaczali sobie jakiś cel, ciężko pracowali, aby go osiagnąć $(2,269)$. Najsłabszymi ogniwami postawy przedsiębiorczej młodzieży akademickiej były: opanowanie w trudnych sytuacjach $(1,905)$, własna ocena przedsiębiorczości $(1,85)$ oraz lubienie przejmowania inicjatywy w realizowanych przedsięwzięciach $(1,751)$ [Andrzejczyk, 2016]. Niska ocena własnego opanowania w trudnych sytuacjach może być spowodowana tym, że wraz z rozwojem cywilizacyjnym jest coraz więcej bodźców oddziałujących na ludzi. Dodatkowo postępuje presja otoczenia, by osiagnąć sukces, a ta wywołuje narastający stres. Problem stresu przejawia się brakiem opanowania w trudnych sytuacjach. Analizując liczebność przedsiębiorców wśród studentów, niska ocena własnej przedsiębiorczości u ogółu studentów nie jest zaskakującym wnioskiem. Zastanawiający jest zaś niski wskaźnik cząstkowy dla stwierdzenia „Lubię przejmować inicjatywę w realizowanych przedsięwzięciach", który sygnalizuje niechęć do przewodzenia grupą w postawach młodzieży akademickiej. 
TABELA 1.

Wskaźniki struktury dla poszczególnych stwierdzeń określających postawy przedsiębiorcze u studentów ogółem w województwie podlaskim

\begin{tabular}{|c|c|c|c|c|c|}
\hline Numer stwierdzeń & $\begin{array}{l}\text { Zdecydo- } \\
\text { wanie nie } \\
-0\end{array}$ & $\begin{array}{l}\text { Raczej nie } \\
-1\end{array}$ & $\begin{array}{l}\text { Raczej tak } \\
\quad-2\end{array}$ & $\begin{array}{l}\text { Zdecydowa- } \\
\text { nie tak }-3\end{array}$ & Razem \\
\hline $\begin{array}{l}\text { 1. Łatwo nawiązuję kontakt } \\
\text { z innymi ludźmi. }\end{array}$ & 2,14 & 9,93 & 51,35 & 36,58 & 100,00 \\
\hline $\begin{array}{l}\text { 2. Nie boję się nietypowych } \\
\text { rozwiązań. }\end{array}$ & 3,59 & 19,26 & 49,45 & 27,70 & 100,00 \\
\hline $\begin{array}{l}\text { 3. Umiem brać odpowie- } \\
\text { dzialność za podejmowa- } \\
\text { ne działania. }\end{array}$ & 1,15 & 2,84 & 35,88 & 60,13 & 100,00 \\
\hline $\begin{array}{l}\text { 4. Posiadam umiejętności } \\
\text { organizacyjne. }\end{array}$ & 1,75 & 11,92 & 50,05 & 36,28 & 100,00 \\
\hline $\begin{array}{l}\text { 5. Pojawiające się problemy } \\
\text { traktuję jako wyzwania. }\end{array}$ & 3,14 & 22,46 & 48,35 & 26,05 & 100,00 \\
\hline $\begin{array}{l}\text { 6. Chętnie angażuję się } \\
\text { w nowe przedsięwzięcia. }\end{array}$ & 2,74 & 21,11 & 52,40 & 23,75 & 100,00 \\
\hline $\begin{array}{l}\text { 7. Lubię przejmować inicja- } \\
\text { tywę w realizowanych } \\
\text { przedsięwzięciach. }\end{array}$ & 6,39 & 34,38 & 36,93 & 22,30 & 100,00 \\
\hline $\begin{array}{l}\text { 8. Latwo dostosowuje się } \\
\text { do zmian zachodzących } \\
\text { w moim otoczeniu. }\end{array}$ & 3,54 & 17,92 & 54,19 & 24,35 & 100,00 \\
\hline $\begin{array}{l}\text { 9. Posiadam wiele pomys- } \\
\text { łów, które chciałabym/ } \\
\text { chciałbym zrealizować. }\end{array}$ & 3,09 & 15,92 & 44,91 & 36,08 & 100,00 \\
\hline $\begin{array}{l}\text { 10. Kiedy wyznaczę sobie } \\
\text { jakiś cel, ciężko pracuję, } \\
\text { by go osiagnąć. }\end{array}$ & 1,50 & 8,98 & 50,65 & 38,87 & 100,00 \\
\hline $\begin{array}{l}\text { 11. Podejmuję działania } \\
\text { w zakresie rozwoju osobis- } \\
\text { tego. }\end{array}$ & 1,10 & 6,93 & 45,86 & 46,11 & 100,00 \\
\hline $\begin{array}{l}\text { 12. W trudnych sytuacjach } \\
\text { jestem opanowana/opano- } \\
\text { wany. }\end{array}$ & 6,04 & 22,06 & 47,30 & 24,60 & 100,00 \\
\hline $\begin{array}{l}13 \text { Uważam, że jestem przed- } \\
\text { siębiorcza/przedsiębior- } \\
\text { czy. }\end{array}$ & 5,34 & 24,05 & 50,90 & 19,71 & 100,00 \\
\hline
\end{tabular}

Źródło: na podstawie badań własnych.

Przedstawione w tabeli 1 . wskaźniki struktury poszczególnych opinii studentów w zakresie wykazywanych przez nich cech pozwalają na określenie dominanty w tych obszarach, i tak, jedynie dla dwóch stwierdzeń (3. i 11.) dominowała odpowiedź „zdecydowanie tak”, a w pozostałych przypadkach odpowiedź „raczej tak”.

Co ciekawe, obserwując ukształtowanie wskaźnika przedsiębiorczości z podziałem badanej grupy według poszczególnych kryteriów (płeć, typ uczelni, stopień studiów itd.), można zauważyć, że we wszystkich badanych grupach najwyższą punktację uzyskało 
stwierdzenie dotyczące umiejętności brania odpowiedzialności za podejmowane działania. W większości dokonanych podziałów respondentów okazuje się, że hierarchia badanych cech, w przypadku trzech najwyżej punktowanych i trzech najniżej punktowanych stwierdzeń, ukształtowała się podobnie jak dla ogółu badanych studentów.

Wskaźnik przedsiębiorczości studiujących kobiet wynosił 2,075 i był nieznacznie niższy od wskaźnika dla ogółu respondentów (2,094), również nieznacznie niższy od wskaźnika w badanej grupie studiujących mężczyzn $(2,127)$ [Andrzejczyk, 2016]. Wynik ten potwierdza utrwalony w nauce pogląd, że poziom przedsiębiorczości kobiet jest niższy niż poziom przedsiębiorczości mężczyzn. Częstym argumentem jest rodzicielstwo. Kobiety, w związku z odmienną rolą społeczna, mogą silniej dążyć do stabilizacji życiowej i rzadziej podejmować ryzykowne przedsięwzięcia.

Analizując poszczególne składniki wskaźnika przedsiębiorczości kobiet, można zauważyć, że studentki w najwyższym stopniu uważały, że umieją brać odpowiedzialność za podejmowane działania $(2,556)$. Następnie podejmowały działania w zakresie rozwoju osobistego $(2,364)$ oraz kiedy wyznaczyły sobie jakiś cel, ciężko pracowały, aby go osiagnąć $(2,31)$. Najsłabszymi ogniwami postawy przedsiębiorczej studiujących kobiet były: opanowanie w trudnych sytuacjach $(1,829)$, własna ocena przedsiębiorczości $(1,805)$ oraz upodobanie w przejmowaniu inicjatywy w realizowanych przedsięwzięciach $(1,729)$. W przypadku mężczyzn dwie najwyższe składowe wskaźnika kształtowały się podobnie jak u kobiet i ogółu respondentów, tj. mężczyźni umieli brać odpowiedzialność za podejmowane działania $(2,539)$ i podejmowali działania w zakresie rozwoju osobistego $(2,381)$. Wyróżniająca się u mężczyzn była trzecia największa wartość składowa postawy przedsiębiorczej, czyli łatwość w nawiązywaniu kontaktów z innymi ludźmi $(2,208)$. Natomiast najsłabszymi ogniwami postawy przedsiębiorczej u mężczyzn były: chęć angażowania się w nowe przedsięwzięcia $(1,956)$, własna ocena przedsiębiorczości $(1,928)$ oraz przejmowanie inicjatywy w realizowanych przedsięwzięciach (1,792) [Andrzejczyk, 2016].

Warto przy tym zwrócić uwagę na to, że wśród kobiet w prawie połowie ocenianych stwierdzeń (w 6 przypadkach) wartości wskaźników przedsiębiorczości były wyższe niż 2, w siedmiu zaś poniżej dwóch. W odniesieniu do mężczyzn, aż 10 wskaźników cząstkowych przyjęło wartości powyżej 2 . W konsekwencji, mimo że trzecią najgorzej ocenioną cechą przedsiębiorczą była w ich przypadku chęć angażowania się w nowe przedsięwzięcia $(1,956)$, to i tak wartość tego wskaźnika cząstkowego była tylko o 0,034 niższa niż u kobiet (1,98), u których ta cecha znalazła się na siódmej pozycji od dołu (licząc od najniższej wykazywanej wartości cząstkowej).

W grupie kobiet w większości cech szczegółowych przeważała odpowiedź „,raczej tak", a jedynie w dwóch stwierdzeniach dominanta była inna (tabela 2.). W stwierdzeniu 3. najczęściej wybieraną odpowiedź stanowiło „zdecydowanie tak”, zaś w stwierdzeniu 7. „raczej nie”. 
TABELA 2.

Wskaźniki struktury dla poszczególnych stwierdzeń określających postawy przedsiębiorcze u studentów płci żeńskiej w województwie podlaskim

\begin{tabular}{|c|c|c|c|c|c|}
\hline $\begin{array}{c}\text { Numer } \\
\text { stwierdzeń }\end{array}$ & $\begin{array}{c}\text { Zdecydowa- } \\
\text { nie nie - - }\end{array}$ & $\begin{array}{c}\text { Raczej nie } \\
\mathbf{- 1}\end{array}$ & $\begin{array}{c}\text { Raczej tak } \\
\mathbf{- 2}\end{array}$ & $\begin{array}{c}\text { Zdecydowa- } \\
\text { nie tak-3 }\end{array}$ & Razem \\
\hline 1. & 1,25 & 9,46 & 54,11 & 35,18 & 100,00 \\
2. & 3,28 & 23,53 & 50,20 & 22,99 & 100,00 \\
3. & 0,70 & 2,82 & 36,67 & 59,81 & 100,00 \\
4. & 1,25 & 11,42 & 49,88 & 37,45 & 100,00 \\
5. & 3,05 & 24,86 & 50,04 & 22,05 & 100,00 \\
6. & 2,11 & 21,42 & 52,78 & 23,69 & 100,00 \\
7. & 6,25 & 36,28 & 35,81 & 21,66 & 100,00 \\
8. & 2,89 & 19,31 & 54,89 & 22,91 & 100,00 \\
9. & 2,58 & 17,20 & 46,36 & 33,86 & 100,00 \\
10. & 0,63 & 7,74 & 51,60 & 40,03 & 100,00 \\
11. & 0,63 & 7,11 & 47,54 & 44,72 & 100,00 \\
12. & 6,18 & 26,35 & 45,89 & 21,58 & 100,00 \\
13. & 4,77 & 26,82 & 51,52 & 16,89 & 100,00 \\
\hline
\end{tabular}

Źródło: na podstawie badań własnych.

TABELA 3.

Wskaźniki struktury dla poszczególnych stwierdzeń określających postawy przedsiębiorcze u studentów płci męskiej w województwie podlaskim

\begin{tabular}{|c|c|c|c|c|c|}
\hline $\begin{array}{c}\text { Numer } \\
\text { stwierdzeń }\end{array}$ & $\begin{array}{c}\text { Zdecydowa- } \\
\text { nie nie - - }\end{array}$ & $\begin{array}{c}\text { Raczej nie } \\
\mathbf{- 1}\end{array}$ & $\begin{array}{c}\text { Raczej tak } \\
\mathbf{- 2}\end{array}$ & $\begin{array}{c}\text { Zdecydowa- } \\
\text { nie tak-3 }\end{array}$ & Razem \\
\hline 1. & 3,73 & 10,76 & 46,48 & 39,03 & 100,00 \\
2. & 4,14 & 11,72 & 48,14 & 36,00 & 100,00 \\
3. & 1,93 & 2,90 & 34,48 & 60,69 & 100,00 \\
4. & 2,62 & 12,83 & 50,34 & 34,21 & 100,00 \\
5. & 3,31 & 18,21 & 45,38 & 33,10 & 100,00 \\
6. & 3,86 & 20,55 & 51,73 & 23,86 & 100,00 \\
7. & 6,62 & 31,03 & 38,90 & 23,45 & 100,00 \\
8. & 4,69 & 15,45 & 52,96 & 26,90 & 100,00 \\
9. & 4,00 & 13,66 & 42,34 & 40,00 & 100,00 \\
10. & 3,03 & 11,17 & 48,97 & 36,83 & 100,00 \\
11. & 1,93 & 6,62 & 42,90 & 48,55 & 100,00 \\
12. & 5,80 & 14,48 & 49,79 & 29,93 & 100,00 \\
13. & 6,35 & 19,17 & 49,79 & 24,69 & 100,00 \\
\hline
\end{tabular}

Źródło: na podstawie badań własnych.

Jednocześnie w grupie mężczyzn w odniesieniu do większości cech szczegółowych można stwierdzić, że dominowała odpowiedź „raczej tak”, a jedynie w dwóch cechach 
dominanta była inna (tabela 3.). Tak, jak u kobiet, w stwierdzeniu 3. najczęściej wybieraną odpowiedzią było „zdecydowanie tak”. Inaczej niż u kobiet zaś kształtowała się dominanta w stwierdzeniu 11., w którym to przeważała odpowiedź „zdecydowanie tak”.

Zaobserwowana wartość wskaźnika postaw przedsiębiorczych u studentów uczelni prywatnych była na poziomie 2,159. Istotne jest przy tym to, że wartość ta była jedną z najwyższych wśród badanych grup (wyższy stopień wykazali jedynie studenci studiów niestacjonarnych: 2,199). Rozkładając wskaźnik dla danej grupy na poszczególne cechy (tabela 4.), można stwierdzić, że studenci uczelni prywatnych w najwyższym stopniu uważali, że umieją brać odpowiedzialność za podejmowane działania $(2,554)$, podejmują działania w zakresie rozwoju osobistego $(2,451)$ i łatwo nawiązuja kontakty $z$ innymi ludźmi $(2,333)$ [Andrzejczyk, 2016]. Wysoki wskaźnik podejmowania działań w zakresie rozwoju osobistego może świadczyć o tym, że studenci uczelni prywatnych podjęli decyzję o swoich studiach bardziej świadomie (płacąc za coś, poświęca się więcej czasu na analizę ,za” i „przeciw” niż, gdy otrzymuje się coś teoretycznie „za darmo”) i również w przypadku inwestowania w samorozwój czynili to bardziej świadomie, bardziej doceniając podjęte starania. Natomiast w najniższym stopniu uważali, że w trudnych sytuacjach są opanowani $(2,015)$, przedsiębiorczy $(2,000)$ i lubią przejmować inicjatywę w realizowanych przedsięwzięciach $(1,936)$. W przypadku studentów uczelni prywatnych tylko jeden, najsłabszy wskaźnik cząstkowy przyjął wartość poniżej 2.

TABELA 4.

Wskaźniki cząstkowe postaw przedsiębiorczych u studentów ogółem, uczelni publicznych i prywatnych w województwie podlaskim

\begin{tabular}{|l|c|c|c|}
\hline \multicolumn{1}{|c|}{ Stwierdzenie } & \multicolumn{3}{c|}{ Wartość wskaźników } \\
& \multicolumn{1}{|c|}{$\begin{array}{c}\text { Uczelnie } \\
\text { publiczne }\end{array}$} & $\begin{array}{c}\text { Uczelnie } \\
\text { prywatne }\end{array}$ & Ogółem \\
\cline { 2 - 4 } & 2,551 & 2,541 & 2,550 \\
1. Umiem brać odpowiedzialność za podejmowane & & & \\
$\quad$ działania. & 2,360 & 2,428 & 2,370 \\
2. Podejmuję działania w zakresie rozwoju osobistego. & 2,260 & 2,322 & 2,269 \\
3. Kiedy wyznaczę sobie jakiś cel, ciężko pracuję, by go & & & \\
$\quad$ osiagnąć. & 2,209 & 2,314 & 2,224 \\
4. Latwo nawiązuję kontakt z innymi ludźmi. & 2,204 & 2,237 & 2,209 \\
5. Posiadam umiejętności organizacyjne. & 2,130 & 2,198 & 2,140 \\
6. Posiadam wiele pomysłów, które chciałabym/chciałbym & & & \\
$\quad$ zrealizować. & 2,016 & 1,993 & 2,012 \\
7. Nie boję się nietypowych rozwiązań. & 1,975 & 2,106 & 1,994 \\
8. Latwo dostosowuję się do zmian zachodzących & 1,962 & 2,039 & 1,973 \\
$\quad$ w moim otoczeniu. & 1,954 & 2,078 & 1,972 \\
9. Pojawiające się problemy traktuję jako wyzwania. & 1,888 & 2,007 & 1,905 \\
10. Chętnie angażuję się w nowe przedsięwzięcia. & & & \\
11. W trudnych sytuacjach jestem opanowana/opano- & 1,830 & 1,968 & 1,850 \\
$\quad$ wany. & 1,737 & 1,841 & 1,751 \\
12. Uważam, że jestem przedsiębiorcza/przedsiębiorczy. & & & \\
13. Lubię przejmować inicjatywę w realizowanych & &
\end{tabular}

Źródło: na podstawie badań własnych. 
Wskaźnik postaw przedsiębiorczych studentów uczelni publicznych wynosił 2,083 i był znacznie niższy niż u studentów uczelni prywatnych. Analizując poszczególne składniki wskaźnika przedsiębiorczości młodzieży studiującej na uczelniach publicznych, za najsilniejsze ogniwa wskaźnika można uznać: odpowiedzialność za podejmowane działania $(2,551)$, następnie podejmowanie działań w zakresie rozwoju osobistego (2,36) oraz ciężką pracę, by osiagnąć wyznaczony cel $(2,26)$ [Andrzejczyk, 2016]. Studenci uczelni publicznych również wysoko oceniali własne działania w zakresie rozwoju osobistego (o 0,91 niżej niż studenci uczelni prywatnych), jednak może to mieć odmienne podłoże. Na uczelniach publicznych było więcej dodatkowych aktywności i możliwości oferowanych studentom (nie tylko przez samą uczelnię, ale i uczelnie/ jednostki współpracujące), np.: konferencje, seminaria, konkursy, koła naukowe. Najsłabsze ogniwa w tej grupie były takie same, jak w grupie studentów uczelni prywatnych („W trudnych sytuacjach jestem opanowana/opanowany”, „Uważam, że jestem przedsiębiorcza/przedsiębiorczy”, „Lubię przejmować inicjatywę w realizowanych przedsięwzięciach”), z tą różnica, że wykazały one niższe wartości, kolejno: 1,888, 1,83 i 1,737 .

TABELA 5.

Wskaźniki struktury dla poszczególnych stwierdzeń określających postawy przedsiębiorcze u studentów uczelni publicznych w województwie podlaskim

\begin{tabular}{|c|c|c|c|c|c|}
\hline $\begin{array}{c}\text { Numer } \\
\text { stwierdzeń }\end{array}$ & $\begin{array}{c}\text { Zdecydowa- } \\
\text { nie nie - 0 }\end{array}$ & $\begin{array}{c}\text { Raczej nie } \\
\mathbf{- 1}\end{array}$ & $\begin{array}{c}\text { Raczej tak } \\
\mathbf{- 2}\end{array}$ & $\begin{array}{c}\text { Zdecydowa } \\
\text { nie tak-3 }\end{array}$ & Razem \\
\hline 1. & 1,92 & 10,63 & 52,12 & 35,33 & 100,00 \\
2. & 3,20 & 19,35 & 50,14 & 27,31 & 100,00 \\
3. & 0,93 & 2,85 & 36,37 & 59,85 & 100,00 \\
4. & 1,57 & 12,55 & 49,80 & 36,08 & 100,00 \\
5. & 3,20 & 22,83 & 48,52 & 25,45 & 100,00 \\
6. & 2,61 & 22,20 & 52,35 & 22,84 & 100,00 \\
7. & 6,33 & 35,62 & 36,08 & 21,97 & 100,00 \\
8. & 3,49 & 18,53 & 54,97 & 23,01 & 100,00 \\
9. & 3,02 & 16,85 & 44,22 & 35,91 & 100,00 \\
10. & 1,34 & 9,53 & 50,90 & 38,23 & 100,00 \\
11. & 0,99 & 7,26 & 46,49 & 45,26 & 100,00 \\
12. & 6,22 & 22,89 & 46,78 & 24,11 & 100,00 \\
13. & 5,64 & 24,69 & 50,67 & 19,00 & 100,00 \\
\hline
\end{tabular}

Źródło: na podstawie badań własnych.

Porównując strukturę odpowiedzi w odniesieniu do poszczególnych stwierdzeń w grupie studentów uczelni publicznych oraz niepublicznych (tabele: 5. i 6.), można dostrzec, że dominowały bardzo podobne odpowiedzi, głównie „raczej tak”, zaś 
w stwierdzeniu trzecim ,zdecydowanie tak”. Odmiennie kształtowała się najpopularniejsza odpowiedź wśród studentów uczelni prywatnych w stwierdzeniu jedenastym, tj. ,zdecydowanie tak".

TABELA 6.

Wskaźniki struktury dla poszczególnych stwierdzeń określających postawy przedsiębiorcze u studentów uczelni niepublicznych w województwie podlaskim

\begin{tabular}{|c|r|r|r|r|r|}
\hline $\begin{array}{c}\text { Numer } \\
\text { stwierdzeń }\end{array}$ & $\begin{array}{c}\text { Zdecydowa- } \\
\text { nie nie - - }\end{array}$ & $\begin{array}{c}\text { Raczej } \\
\text { nie - - }\end{array}$ & $\begin{array}{c}\text { Raczej } \\
\text { tak - 2 }\end{array}$ & $\begin{array}{c}\text { Zdecydowa- } \\
\text { nie tak - 3 }\end{array}$ & Razem \\
\hline 1. & 3,53 & 5,66 & 46,64 & 44,17 & 100,00 \\
2. & 6,01 & 18,73 & 45,23 & 30,03 & 100,00 \\
3. & 2,47 & 2,83 & 32,86 & 61,84 & 100,00 \\
4. & 2,83 & 8,13 & 51,59 & 37,45 & 100,00 \\
5. & 2,83 & 20,14 & 47,35 & 29,68 & 100,00 \\
6. & 3,53 & 14,49 & 52,65 & 29,33 & 100,00 \\
7. & 6,71 & 26,86 & 42,05 & 24,38 & 100,00 \\
8. & 3,89 & 14,13 & 49,47 & 32,51 & 100,00 \\
9. & 3,53 & 10,25 & 49,12 & 37,10 & 100,00 \\
10. & 2,47 & 5,65 & 49,12 & 42,76 & 100,00 \\
11. & 1,77 & 4,95 & 42,05 & 51,23 & 100,00 \\
12. & 4,95 & 16,96 & 50,53 & 27,56 & 100,00 \\
13. & 3,53 & 20,14 & 52,30 & 24,03 & 100,00 \\
\hline
\end{tabular}

Źródło: na podstawie badań własnych.

Ogólna wartość wskaźnika przedsiębiorczości studentów studiów stacjonarnych wynosiła 2,040 i była trzecią z najniższych wartości tego wskaźnika, zaobserwowaną w badaniu. Jest to o tyle ciekawe, że w przypadku studentów studiów niestacjonarnych wskaźnik ten wynosił 2,199 i był najwyższy w badanej próbie [Andrzejczyk, 2016].

Rozpatrując poszczególne ogniwa wskaźnika postaw przedsiębiorczych studentów studiów stacjonarnych (tabela 7.), za najważniejsze należy uznać: umiejętność brania odpowiedzialności za podejmowane działania $(2,548)$, podejmowanie działania w zakresie rozwoju osobistego $(2,329)$ i ciężka praca, by osiagnąć wyznaczony cel $(2,238)$. Natomiast najsłabszymi ogniwami postawy przedsiębiorczej u studentów studiów stacjonarnych były: opanowanie w trudnych sytuacjach $(1,849)$, samoocena przedsiębiorczości $(1,774)$ oraz przejmowanie inicjatywy w realizowanych przedsięwzięciach $(1,658)$. W przypadku studentów studiów niestacjonarnych dwie najwyższe składowe wskaźnika kształtowały się podobnie jak u studentów studiów stacjonarnych, tj. studenci ci umieją brać odpowiedzialność za podejmowane działania $(2,554)$ i podejmują działania w zakresie rozwoju osobistego $(2,451)$. Różnica dotyczyła trzeciej, większej wartości składowej postawy przedsiębiorczej, czyli łatwości w nawiązywaniu kontaktów z innymi ludźmi $(2,333)$. Najsłabsze ogniwa w tej grupie były takie same, jak w grupie 
uczestników studiów stacjonarnych (,,W trudnych sytuacjach jestem opanowana/ opanowany”, „Uważam, że jestem przedsiębiorcza/przedsiębiorczy”, „Lubię przejmować inicjatywę w realizowanych przedsięwzięciach"), z tą różnica, że wykazały wyższe wartości (kolejno: 2,015, 2,000 i 1,936). Wśród studentów studiów niestacjonarnych zatem tylko jeden wskaźnik cząstkowy był niższy od 2 [Andrzejczyk, 2016].

TABELA 7.

Wskaźniki cząstkowe postaw przedsiębiorczych u studentów ogółem, studiów stacjonarnych i niestacjonarnych $\mathrm{w}$ województwie podlaskim

\begin{tabular}{|l|c|c|c|}
\hline \multicolumn{1}{|c|}{ Stwierdzenie } & \multicolumn{2}{c|}{ Wartość wskaźników } \\
& \multicolumn{1}{|c|}{ cząstkowych } \\
\cline { 2 - 4 } & $\begin{array}{c}\text { Studia sta- } \\
\text { cjonarne }\end{array}$ & $\begin{array}{c}\text { Studia nie- } \\
\text { stacjonarne }\end{array}$ & Ogółem \\
\hline 1. Umiem brać odpowiedzialność za podejmo- & 2,548 & 2,554 & 2,550 \\
wane działania. & & & \\
2. Podejmuję działania w zakresie rozwoju osobi- & 2,329 & 2,451 & 2,370 \\
stego. & & & \\
3. Kiedy wyznaczę sobie jakiś cel, ciężko pracuję, & 2,238 & 2,330 & 2,269 \\
by go osiagnąć. & 2,168 & 2,333 & 2,224 \\
4. Latwo nawiązuję kontakt z innymi ludźmi. & 2,168 & 2,289 & 2,209 \\
5. Posiadam umiejętności organizacyjne. & 2,103 & 2,213 & 2,140 \\
6. Posiadam wiele pomysłów, które chciała- & 1,884 & 2,146 & 2,012 \\
bym/chciałbym zrealizować. & 1,958 & 2,121 & 1,994 \\
7. Chętnie angażuję się w nowe przedsięwzięcia. & 1,906 & 2,106 & 1,973 \\
8. Nie boję się nietypowych rozwiązań. & 1,940 & 2,100 & 1,972 \\
9. Pojawiające się problemy traktuję jako wyzwania. & 1,849 & 2,015 & 1,905 \\
10. Latwo dostosowuję się do zmian zachodzą- & & 2,000 & 1,850 \\
cych w moim otoczeniu. & 1,774 & 1,936 & 1,751 \\
11. W trudnych sytuacjach jestem opano- & & & \\
wana/opanowany. & & & \\
12. Uważam, że jestem przedsiębior- & & & \\
cza/przedsiębiorczy. & & & \\
13. Lubię przejmować inicjatywę w realizowa- & & \\
nych przedsięwzięciach. & & & \\
\hline
\end{tabular}

Źródło: na podstawie badań własnych. 
TABELA 8.

Wskaźniki struktury dla poszczególnych stwierdzeń określających postawy przedsiębiorcze $\mathrm{u}$ studentów stacjonarnych $\mathrm{w}$ województwie podlaskim

\begin{tabular}{|c|r|r|r|r|r|}
\hline $\begin{array}{c}\text { Numer } \\
\text { stwierdzeń }\end{array}$ & $\begin{array}{c}\text { Zdecydowa- } \\
\text { nie nie - 0 }\end{array}$ & $\begin{array}{c}\text { Raczej } \\
\text { nie-1 }\end{array}$ & $\begin{array}{c}\text { Raczej } \\
\text { tak-2 }\end{array}$ & $\begin{array}{c}\text { Zdecydowa- } \\
\text { nie tak-3 }\end{array}$ & Razem \\
\hline 1. & 1,95 & 11,94 & 53,45 & 32,66 & 100,00 \\
2. & 3,30 & 21,62 & 51,05 & 24,03 & 100,00 \\
3. & 0,83 & 2,78 & 37,16 & 59,23 & 100,00 \\
4. & 1,58 & 13,59 & 51,27 & 33,56 & 100,00 \\
5. & 3,53 & 24,77 & 49,25 & 22,45 & 100,00 \\
6. & 3,23 & 23,80 & 54,35 & 18,62 & 100,00 \\
7. & 7,21 & 39,04 & 34,46 & 19,29 & 100,00 \\
8. & 3,53 & 19,52 & 56,38 & 20,57 & 100,00 \\
9. & 3,00 & 18,47 & 43,77 & 34,76 & 100,00 \\
10. & 1,35 & 9,98 & 52,18 & 36,49 & 100,00 \\
11. & 0,90 & 8,26 & 47,90 & 42,94 & 100,00 \\
12. & 6,38 & 24,55 & 46,85 & 22,22 & 100,00 \\
13. & 6,01 & 27,03 & 50,52 & 16,44 & 100,00 \\
\hline
\end{tabular}

Źródło: na podstawie badań własnych.

Porównując strukturę odpowiedzi w odniesieniu do poszczególnych stwierdzeń w grupie studentów stacjonarnych oraz niestacjonarnych (tabele: 8. i 9.), można dostrzec, że również przeważały głównie odpowiedzi „raczej tak”, zaś w stwierdzeniu trzecim „zdecydowanie tak”. Inaczej było w przypadku stwierdzenia siódmego, w którym to u studentów stacjonarnych najpopularniejszą odpowiedzią było „raczej nie”, natomiast w stwierdzeniu jedenastym wśród studentów uczelni prywatnych dominowało „zdecydowanie tak".

W grupie studentów studiów pierwszego stopnia wartość wskaźnika przedsiębiorczości wyniosła 2,093. Nieco wyższą wartość zaobserwowano u studentów studiów drugiego stopnia - 2,114, zaś u studentów studiów jednolitych magisterskich wartość wskaźnika wyniosła 2,058 [Andrzejczyk, 2016]. Według wszystkich trzech grup, zarówno trzy najsilniejsze składniki cząstkowe wskaźnika, jak i trzy najsłabsze wskaźniki cząstkowe kształtowały się bardzo podobnie, różniąc się jedynie nasileniem składowych (tabela 10.). Najsilniejszymi ogniwami postawy przedsiębiorczej w tych trzech grupach były kolejno: umiejętność brania odpowiedzialności za podejmowane działania, podejmowanie działania w zakresie rozwoju osobistego i ciężka praca, by osiagnąć wyznaczony cel. Najsłabszymi składnikami wskaźnika przedsiębiorczości były następujące: opanowanie w trudnych sytuacjach, własna ocena przedsiębiorczości i upodobanie w przejmowaniu inicjatywy w realizowanych przedsięwzięciach. 
TABELA 9.

Wskaźniki struktury dla poszczególnych stwierdzeń określających postawy przedsiębiorcze u studentów niestacjonarnych w województwie podlaskim

\begin{tabular}{|c|r|r|r|r|r|}
\hline $\begin{array}{c}\text { Numer } \\
\text { stwierdzeń }\end{array}$ & $\begin{array}{r}\text { Zdecydowa- } \\
\text { nie nie - 0 }\end{array}$ & $\begin{array}{c}\text { Raczej } \\
\text { nie - 1 }\end{array}$ & $\begin{array}{c}\text { Raczej } \\
\text { tak - 2 }\end{array}$ & $\begin{array}{c}\text { Zdecydowa- } \\
\text { nie tak - 3 }\end{array}$ & Razem \\
\hline 1. & 2,53 & 5,95 & 47,17 & 44,35 & 100,00 \\
2. & 4,17 & 14,58 & 46,28 & 34,97 & 100,00 \\
3. & 1,79 & 2,98 & 33,33 & 61,90 & 100,00 \\
4. & 2,08 & 8,63 & 47,62 & 41,67 & 100,00 \\
5. & 2,38 & 17,86 & 46,58 & 33,18 & 100,00 \\
6. & 1,79 & 15,77 & 48,51 & 33,93 & 100,00 \\
7. & 4,76 & 25,15 & 41,82 & 28,27 & 100,00 \\
8. & 3,57 & 14,73 & 49,85 & 31,85 & 100,00 \\
9. & 3,28 & 10,86 & 47,17 & 38,69 & 100,00 \\
10. & 1,79 & 6,99 & 47,62 & 43,60 & 100,00 \\
11. & 1,49 & 4,315 & 41,815 & 52,38 & 100,00 \\
12. & 5,36 & 17,11 & 48,21 & 29,32 & 100,00 \\
13. & 4,02 & 18,15 & 51,64 & 26,19 & 100,00 \\
\hline
\end{tabular}

Źródło: na podstawie badań własnych.

W przypadku studentów studiów pierwszego stopnia trzy najsilniejsze ogniwa przyjęły wartości: 2,553, 2,38 i 2,255, zaś trzy najsłabsze: 1,918, 1,841 i 1,735. Dla uczestników studiów drugiego stopnia trzy najwyższe składniki wskaźnika wynosiły: 2,546, 2,367 i 2,303, natomiast trzy najniższe: 1,909, 1,906 i 1,811. W przypadku studentów studiów jednolitych trzy najsilniejsze ogniwa przyjęły wartości: 2,539, 2,317 i 2,284, a trzy najsłabsze: 1,827, 1,794 i 1,733 [Andrzejczyk, 2016]. 
TABELA 10.

Wskaźniki cząstkowe postaw przedsiębiorczych u studentów ogółem, studiów pierwszego stopnia, drugiego stopnia i studiów jednolitych magisterskich w województwie podlaskim

\begin{tabular}{|c|c|c|c|}
\hline \multirow[b]{2}{*}{ Numer stwierdzeń } & \multicolumn{3}{|c|}{ Wartość wskaźników cząstkowych } \\
\hline & $\begin{array}{c}\text { Pierwszy sto- } \\
\text { pień }\end{array}$ & Drugi stopień & $\begin{array}{l}\text { Jednolite magi- } \\
\text { sterskie }\end{array}$ \\
\hline $\begin{array}{l}\text { 1. Umiem brać odpowiedzial- } \\
\text { ność za podejmowane dzia- } \\
\text { łania. }\end{array}$ & 2,553 & 2,546 & 2,539 \\
\hline $\begin{array}{l}\text { 2. Podejmuje działania w zak- } \\
\text { resie rozwoju osobistego. }\end{array}$ & 2,380 & 2,367 & 2,317 \\
\hline $\begin{array}{l}\text { 3. Kiedy wyznaczę sobie jakiś } \\
\text { cel, ciężko pracuję, by go } \\
\text { osiagnąć. }\end{array}$ & 2,255 & 2,303 & 2,284 \\
\hline $\begin{array}{l}\text { 4. Latwo nawiązuję kontakt } \\
\text { z innymi ludźmi. }\end{array}$ & 2,236 & 2,247 & 2,111 \\
\hline $\begin{array}{l}\text { 5. Posiadam umiejętności or- } \\
\text { ganizacyjne. }\end{array}$ & 2,198 & 2,238 & 2,21 \\
\hline $\begin{array}{l}\text { 6. Posiadam wiele pomysłów, } \\
\text { które chciałabym/ chciał- } \\
\text { bym zrealizować. }\end{array}$ & 2,145 & 2,151 & 2,091 \\
\hline $\begin{array}{l}\text { 7. Nie boję się nietypowych } \\
\text { rozwiązań. }\end{array}$ & 2,010 & 2,007 & 2,037 \\
\hline $\begin{array}{l}\text { 8. Latwo dostosowuje się do } \\
\text { zmian zachodzacych w moim } \\
\text { otoczeniu. }\end{array}$ & 2,007 & 2,011 & 1,889 \\
\hline $\begin{array}{l}\text { 9. Pojawiające się problemy } \\
\text { traktuję jako wyzwania. }\end{array}$ & 1,972 & 1,996 & 1,938 \\
\hline $\begin{array}{l}\text { 10. Chętnie angażuję się w no- } \\
\text { we przedsięwzięcia. }\end{array}$ & 1,961 & 1,996 & 1,984 \\
\hline $\begin{array}{l}\text { 11. W trudnych sytuacjach jes- } \\
\text { tem opanowana/opanowa- } \\
\text { ny. }\end{array}$ & 1,918 & 1,909 & 1,827 \\
\hline $\begin{array}{l}\text { 12. Uważam, że jestem przed- } \\
\text { siębiorcza/przedsiębiorczy. }\end{array}$ & 1,841 & 1,906 & 1,794 \\
\hline $\begin{array}{l}\text { 13. Lubię przejmować inicja- } \\
\text { tywę w realizowanych } \\
\text { przedsięwzięciach. }\end{array}$ & 1,735 & 1,811 & 1,733 \\
\hline
\end{tabular}

Źródło: na podstawie badań własnych. 
TABELA 11.

Wskaźniki struktury dla poszczególnych stwierdzeń określających postawy przedsiębiorcze u studentów pierwszego stopnia w województwie podlaskim

\begin{tabular}{|c|r|r|r|r|r|}
\hline $\begin{array}{c}\text { Numer } \\
\text { stwierdzeń }\end{array}$ & $\begin{array}{c}\text { Zdecydowa- } \\
\text { nie nie - - }\end{array}$ & $\begin{array}{c}\text { Raczej } \\
\text { nie - 1 }\end{array}$ & $\begin{array}{c}\text { Raczej } \\
\text { tak-2 }\end{array}$ & $\begin{array}{c}\text { Zdecydowa- } \\
\text { nie tak-3 }\end{array}$ & Razem \\
\hline 1. & 1,75 & 9,99 & 51,14 & 37,12 & 100,00 \\
2. & 3,81 & 19,66 & 48,25 & 28,28 & 100,00 \\
3. & 1,22 & 2,51 & 35,98 & 60,29 & 100,00 \\
4. & 1,60 & 11,74 & 51,90 & 34,76 & 100,00 \\
5. & 2,97 & 22,56 & 48,78 & 25,69 & 100,00 \\
6. & 2,74 & 21,42 & 52,82 & 23,02 & 100,00 \\
7. & 6,93 & 35,29 & 35,14 & 22,64 & 100,00 \\
8. & 3,35 & 18,06 & 53,13 & 25,46 & 100,00 \\
9. & 3,35 & 15,85 & 43,75 & 37,05 & 100,00 \\
10. & 1,45 & 9,45 & 51,30 & 37,80 & 100,00 \\
11. & 1,14 & 6,10 & 46,34 & 46,42 & 100,00 \\
12. & 6,10 & 21,80 & 46,34 & 25,76 & 100,00 \\
13. & 5,64 & 23,63 & 51,75 & $18,98 / / /$ & 100,00 \\
\hline
\end{tabular}

Zródło: na podstawie badań własnych.

TABELA 12.

Wskaźniki struktury dla poszczególnych stwierdzeń określających postawy przedsiębiorcze u studentów drugiego stopnia w województwie podlaskim

\begin{tabular}{|c|r|r|r|r|r|}
\hline $\begin{array}{c}\text { Numer } \\
\text { stwierdzeń }\end{array}$ & $\begin{array}{c}\text { Zdecydowa- } \\
\text { nie nie - - }\end{array}$ & $\begin{array}{c}\text { Raczej } \\
\text { nie - - }\end{array}$ & $\begin{array}{c}\text { Raczej } \\
\text { tak - 2 }\end{array}$ & $\begin{array}{c}\text { Zdecydowa- } \\
\text { nie tak - 3 }\end{array}$ & Razem \\
\hline 1. & 2,45 & 8,68 & 50,56 & 38,31 & 100,00 \\
2. & 4,23 & 16,70 & 53,23 & 25,84 & 100,00 \\
3. & 1,34 & 2,90 & 35,63 & 60,13 & 100,00 \\
4. & 2,00 & 11,36 & 47,44 & 39,20 & 100,00 \\
5. & 3,56 & 20,27 & 49,22 & 26,95 & 100,00 \\
6. & 3,12 & 19,60 & 51,89 & 25,39 & 100,00 \\
7. & 5,34 & 30,96 & 40,98 & 22,72 & 100,00 \\
8. & 3,79 & 16,03 & 55,46 & 24,72 & 100,00 \\
9. & 3,12 & 14,70 & 46,10 & 36,08 & 100,00 \\
10. & 2,00 & 7,80 & 48,11 & 42,09 & 100,00 \\
11. & 1,34 & 6,90 & 45,43 & 46,33 & 100,00 \\
12. & 5,34 & 21,83 & 49,44 & 23,39 & 100,00 \\
13. & 4,23 & 21,83 & 53,01 & 20,93 & 100,00 \\
\hline
\end{tabular}

Zródło: na podstawie badań własnych. 
TABELA 13.

Wskaźniki struktury dla poszczególnych stwierdzeń określających postawy przedsiębiorcze u studentów studiów jednolitych magisterskich w województwie podlaskim

\begin{tabular}{|c|r|r|r|r|r|}
\hline $\begin{array}{c}\text { Numer } \\
\text { stwierdzeń }\end{array}$ & $\begin{array}{c}\text { Zdecydowa- } \\
\text { nie nie - - }\end{array}$ & $\begin{array}{c}\text { Raczej } \\
\text { nie - - }\end{array}$ & $\begin{array}{c}\text { Raczej } \\
\text { tak-2 }\end{array}$ & $\begin{array}{c}\text { Zdecydowa- } \\
\text { nie tak - 3 }\end{array}$ & Razem \\
\hline 1. & 3,70 & 11,94 & 53,91 & 30,45 & 100,00 \\
2. & 1,24 & 21,81 & 48,97 & 27,98 & 100,00 \\
3. & 0,41 & 4,53 & 35,80 & 59,26 & 100,00 \\
4. & 2,06 & 13,99 & 44,86 & 39,09 & 100,00 \\
5. & 3,29 & 25,93 & 44,44 & 26,34 & 100,00 \\
6. & 2,06 & 22,22 & 51,03 & 24,69 & 100,00 \\
7. & 5,35 & 35,80 & 39,10 & 19,75 & 100,00 \\
8. & 4,11 & 20,58 & 57,61 & 17,70 & 100,00 \\
9. & 1,65 & 18,52 & 48,97 & 30,86 & 100,00 \\
10. & 0,82 & 8,64 & 51,85 & 38,69 & 100,00 \\
11. & 0,41 & 11,53 & 44,03 & 44,03 & 100,00 \\
12. & 6,99 & 23,87 & 48,56 & 20,58 & 100,00 \\
13. & 5,76 & 30,45 & 42,39 & 21,40 & 100,00 \\
\hline
\end{tabular}

Źródło: na podstawie badań własnych.

We wszystkich trzech grupach analizowanych w tabelach: 11.-13. na podstawie poszczególnych wskaźników struktury można zauważyć, że w stwierdzeniu trzecim przeważała odpowiedź ,zdecydowanie tak”. Wśród studentów pierwszego stopnia w stwierdzeniu siódmym dominantę stanowiła odpowiedź „raczej nie”, która była jedynie nieznacznie bardziej popularna od odpowiedzi „raczej tak”. W stwierdzeniu jedenastym we wszystkich grupach odpowiedzi ,zdecydowanie tak” i ,raczej tak” wykazywały bardzo zbliżony udział, jednakże w grupie studentów pierwszego i drugiego stopnia nieznacznie przeważała ta pierwsza. U studentów studiów jednolitych magisterskich obie te odpowiedzi miały taki sam udział $(44,03 \%)$. W pozostałych przypadkach dominantę stanowiła odpowiedź ,raczej tak”.

Wartość wskaźnika postawy przedsiębiorczej u studentów pierwszego stopnia, będących na pierwszym roku studiów, wynosiła 2,087, nieco mniej, 2,067 stanowiła u studentów będących na drugim roku studiów, a najwięcej, 2,125, u uczestników ostatniego roku. Dwa najwyższe wskaźniki cząstkowe u poszczególnych roczników dotyczyły brania odpowiedzialności za podejmowane działania i podejmowania działań w zakresie rozwoju osobistego. Trzeci najwyższy wskaźnik cząstkowy u studentów pierwszego i trzeciego roku był taki sam („Kiedy wyznaczę sobie cel, ciężko pracuję, by go osiagnąć”). Odmiennie było w przypadku studentów drugiego roku, u których na trzeciej pozycji znalazła się cecha łatwego nawiązywania kontaktu z innymi ludźmi. Trzy najsłabsze ogniwa postawy przedsiębiorczej młodzieży akademickiej, będącej na pierwszym 
stopniu studiów z podziałem tej grupy na rok studiów, były takie same we wszystkich grupach i odpowiadały trzem najniżej punktowanym wskaźnikom według ogółu badanych studentów (opanowanie w trudnych sytuacjach, własna ocena przedsiębiorczości oraz przejmowanie inicjatywy w realizowanych przedsięwzięciach).

Wartość wskaźnika przedsiębiorczości studentów drugiego stopnia, będących na pierwszym roku, wyniosła 2,129, zaś u studentów, będących na drugim roku, wartość tego wskaźnika stanowiła 2,088. Rozkładając wskaźnik dla studentów pierwszego roku, można stwierdzić, że studenci ci w najwyższym stopniu umieli brać odpowiedzialność za podejmowane działania $(2,562)$. Następnie studenci ci podejmowali działania w zakresie rozwoju osobistego $(2,377)$ oraz kiedy wyznaczali sobie jakiś cel, ciężko pracowali, aby go osiągnąc $(2,308)$. W przypadku studentów drugiego roku trzy najwyższe wskaźniki cząstkowe były takie same, jedynie przyjmowały niższe wartości, kolejno: 2,516, 2,350 i 2,293. Najsłabszymi ogniwami postawy przedsiębiorczej młodzieży akademickiej, będącej na pierwszym roku omawianego stopnia studiów, były: opanowanie $\mathrm{w}$ trudnych sytuacjach $(1,942)$, samoocena przedsiębiorcza $(1,918)$ i chęć przejmowania inicjatywy $\mathrm{w}$ realizowanych przedsięwzięciach $(1,829)$. U studentów drugiego roku hierarchia trzech najniższych wskaźników cząstkowych kształtowała się nieco odmiennie. Otóż najniższy był wskaźnik cząstkowy, określony jako lubienie przejmowania inicjatywy $\mathrm{w}$ realizowanych przedsięwzięciach $(1,777)$, kolejne były: opanowanie w trudnych sytuacjach $(1,847)$ oraz własna ocena przedsiębiorcza $(1,885)$.

Ogólna wartość wskaźnika postaw przedsiębiorczych studentów studiów jednolitych magisterskich, według podziału na lata studiów, kształtowała się następująco: dla studentów pierwszego roku -2,132; dla studentów drugiego roku - 1,879; dla studentów trzeciego roku - 2,003; dla studentów czwartego roku - 2,113; zaś dla studentów piątego roku -1,959. Oznacza to, że studenci drugiego i piątego roku jednolitych studiów magisterskich wykazywali słabą postawę przedsiębiorczą. Najniższy ogólny wskaźnik przedsiębiorczości u studentów studiów jednolitych był spowodowany tym, że taka forma edukacji głównie pozostała na kierunkach: medycznych, prawnych i artystycznych. Tymczasem własną działalność gospodarcza, zgodną z profilem kształcenia np. prawnym, można założyć dopiero po uzyskaniu odpowiednich uprawnień zawodowych.

Analizując poszczególne składniki wskaźnika przedsiębiorczości dla młodzieży akademickiej uczęszczającej na studia jednolite (z uwzględnieniem poszczególnych lat studiów), można zauważyć, że w badanych grupach zarówno trzy najwyższe, jak i trzy najniższe wskaźniki cząstkowe różniły się od siebie. W stosunku do studentów pierwszego roku najwyżej oceniono to, że umieją brać odpowiedzialność za podejmowane działania $(2,522)$, podejmują działania w zakresie rozwoju osobistego $(2,424)$ oraz ciężko pracują by osiagnać wyznaczony cel, kiedy go sobie wyznacza $(2,293)$. Najsłabszymi ogniwami były: ocena własnej przedsiębiorczości $(1,891)$, opanowanie w trudnych sytuacjach $(1,859)$ i przejmowanie inicjatywy w realizowanych przedsięwzięciach $(1,761)$. W odniesieniu do studentów drugiego roku najwyższe składniki cząstkowe dotyczyły: brania odpowiedzialności za podejmowane działania - 2,571, łatwego dostosowywania się do zmian zachodzących we własnym otoczeniu - 2,143, i tyle samo, 2,143 obejmowało posiadanie wielu pomysłów, które chcieliby zrealizować. Najniższe składniki 
cząstkowe wskaźnika postawy przedsiębiorczej dla tej grupy respondentów dotyczyły: przejmowania inicjatywy w realizowaniu przedsięwzięć $(1,500)$, samooceny przedsiębiorczej $(1,500)$ i traktowania jako wyzwania pojawiających się problemów $(1,429)$. Najsilniejszymi ogniwami wskaźnika przedsiębiorczości u studentów trzeciego roku były: „Umiem brać odpowiedzialność za podejmowane działania” - 2,500; „Kiedy wyznaczę sobie cel, ciężko pracuję, by go osiagnąć” - 2,293; „Podejmuję działania w zakresie rozwoju osobistego" - 2,261. Do trzech najsłabszych ogniw zaś należały: łatwość dostosowywania się do zmian zachodzących we własnym otoczeniu $(1,783)$, przejmowanie inicjatywy $\mathrm{w}$ realizowanych przedsięwzięciach $(1,685)$ oraz samoocena przedsiębiorczości $(1,674)$.

Studenci czwartego roku umieli brać odpowiedzialność za podejmowane działania $(2,767)$, posiadali umiejętności organizacyjne $(2,400)$, kiedy wyznaczali sobie jakiś cel, to ciężko pracowali, by go osiagnąć $(2,400)$, a także podejmowali działania w zakresie rozwoju osobistego $(2,400)$. Trzy najniższe wartości wskaźników cząstkowych należały do stwierdzeń: „Lubię przejmować inicjatywę w realizowanych przedsięwzięciach” 1,867; „, Latwo dostosowuje się do zmian zachodzących w moim otoczeniu” - 1,833; „W trudnych sytuacjach jestem opanowana/opanowany" - 1,767. Ostatnią omawianą grupa byli studenci piątego roku studiów jednolitych magisterskich, u których najwyższy wskaźnik cząstkowy łączył się z umiejętnością brania odpowiedzialności za podejmowane działania $(2,400)$. Następnie studenci ciężko pracowali, by osiagnąć wyznaczony cel $(2,133)$ i podejmowali działania w zakresie rozwoju osobistego $(2,067)$. Tymczasem najniższe wskaźniki cząstkowe obejmowały: łatwość w dostosowywaniu się do zmian zachodzących we własnym otoczeniu $(1,733)$, brak obaw przed nietypowymi rozwiązaniami $(1,800)$ i przejmowanie inicjatywy w realizowanych przedsięwzięciach $(1,800)$.

Drugą część analizy stanowiła przedsiębiorczość studentów w wymiarze prowadzenia lub samej chęci prowadzenia własnej działalności gospodarczej. W badanej próbie jedynie $5,24 \%$ studentów podlaskich uczelni w dniu badania prowadzi i/lub prowadziło własną działalność gospodarcza, w tym 3,2\% kobiet i 8,8\% mężczyzn (rysunek 14.) [Andrzejczyk, 2016]. Oznacza to, że nie tylko w przypadku cech przedsiębiorczych, ale również w wymiarze prowadzenia własnej działalności gospodarczej mężczyźni wykazywali wyższe zainteresowanie przedsiębiorczością od kobiet. Wartość współczynnika kontyngencji C Pearsona wynosiła 0,125 , co wiązało się z bardzo słabą zależnością pomiędzy płcią a prowadzeniem własnej działalności gospodarczej, przy czym ta zależność była istotna, gdyż istotność przybliżona równała się 0,000 , czyli była niższa niż wartość graniczna 0,05 . 
RYSUNEK 14. Udział studentów z poszczególnych grup, którzy prowadzą i/lub prowadzili w dniu badania własną działalność gospodarczą

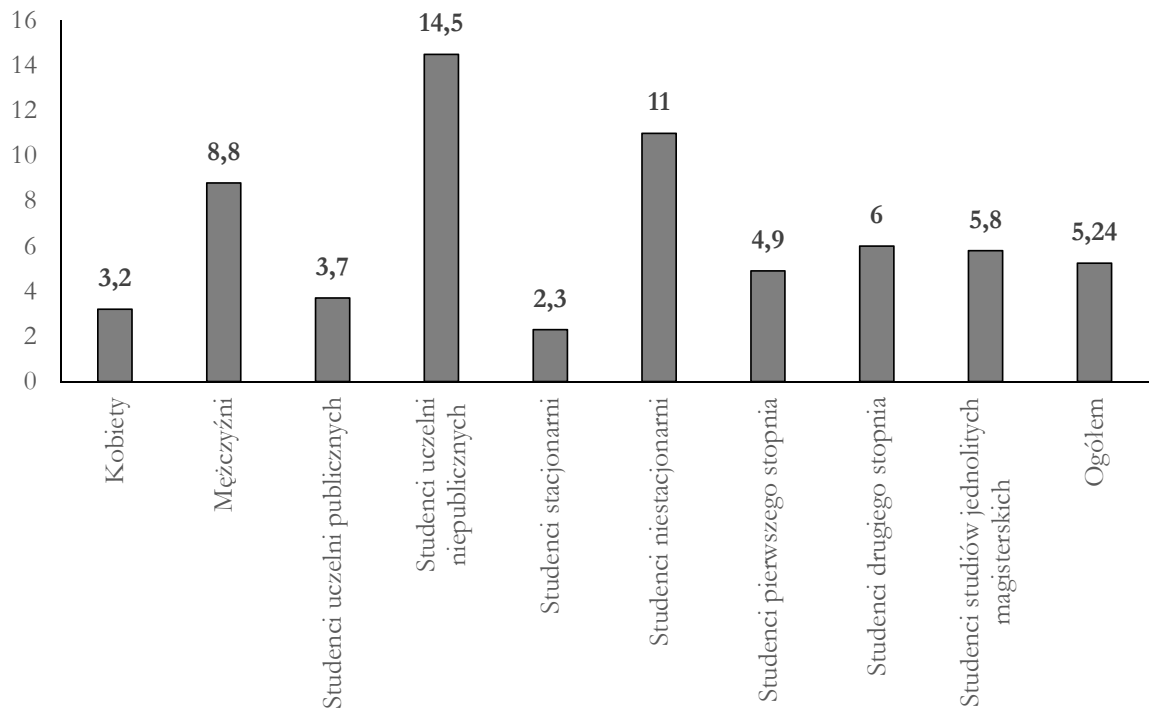

Źródło: na podstawie badań własnych.

W przypadku studentów, według typów uczelni, działalność gospodarczą prowadzi i/lub prowadziło 3,7\% studentów uczelni publicznych oraz aż 14,5\% studentów uczelni niepublicznych [Andrzejczyk, 2016]. Oznacza to, że osoby studiujące w szkołach prywatnych były zdecydowanie bardziej przedsiębiorcze od tych studiujących na uczelniach publicznych, również w wymiarze prowadzenia własnej działalności gospodarczej. Taki wynik mógł być spowodowany tym, że osoby prowadzące własną działalność gospodarcza, chcąc uzupełnić wykształcenie czy też zdobyć wykształcenie wyższe, mogły w tym celu częściej wybierać uczelnie prywatne. Nie jest to jednak tak jednoznaczne. Wartość współczynnika kontyngencji dla tych obserwacji wynosiła 0,163 , co wynika z bardzo słabej zależności pomiędzy badanymi zmiennymi, ale ta zależność, tak jak w przypadku płci, była istotna (istotność przybliżona wynosiła $0,000<0,05$ ).

W podziale badanej grupy na tryb studiów także można było zaobserwować zasadnicze różnice w przedsiębiorczości studentów. Otóż 2,3\% studentów uczących się w trybie stacjonarnym (dziennym) prowadzi i/lub prowadziło własną działalność gospodarczą. U studentów studiów niestacjonarnych (zaocznych) udział ten był znacznie wyższy i wynosił aż 11\% [Andrzejczyk, 2016]. Świadczy to o tym, że osoby przedsiębiorcze mogły chętniej wybierać niestacjonarny tryb kształcenia bądź dokształcania. Prowadząc własną działalność gospodarcza, wybór trybu zaocznego był podyktowany efektywnym wykorzystaniem czasu, a mianowicie poprzez podział na naukę w weekendy i na pracę w ciagu pozostałych dni tygodnia. Studenci studiów trybu niestacjonarnego mogli wykazywać wyższe zainteresowanie prowadzeniem własnej działalności gospodarczej 
zarazem dlatego, że na tego typu studiach mieli dostęp do syntetycznego materiału na zajęciach. Materiał ten szybciej można opanować i wykorzystać we własnej działalności. Wartość współczynnika kontyngencji dla tych obserwacji wynosiła 0,186 , co oznacza bardzo słabą zależność pomiędzy badanymi zmiennymi, przy czym ta zależność była istotna (istotność przybliżona równała się 0,000 , i była niższa od 0,05 ).

Działalność gospodarczą prowadzi i/lub prowadziło 4,9\% studentów pierwszego stopnia, $6,0 \%$ studentów drugiego stopnia oraz 5,8\% studentów studiów jednolitych [Andrzejczyk, 2016]. Wartość współczynnika kontyngencji dla tych obserwacji wynosiła 0,017 , co dowodzi bardzo słabej zależności pomiędzy badanymi zmiennymi, przy czym ta zależność okazała się nieistotna (istotność przybliżona wynosiła 0,742 i była znacznie wyższa od 0,05).

Jednocześnie dokonano analizy przedsiębiorczości wśród studentów z uwagi na rok studiów. W przypadku studentów studiów pierwszego stopnia przyjęto podział na uczestników: pierwszego, drugiego i trzeciego roku studiów. Na studiach inżynierskich, które trwaja przeważnie 3,5 roku, studenci ostatniego semestru stanowili znikomą część badanej próby (mniej niż 0,001\%), dlatego też zostali oni zakwalifikowani jako studenci trzeciego roku. Na studiach pierwszego roku własną działalność gospodarczą prowadzi i/lub prowadziło 3,1\% studentów pierwszego roku, 5,5\% studentów drugiego roku i 5,3\% studentów trzeciego roku. Wartość współczynnika kontyngencji dla tych obserwacji wynosiła 0,045 , co wiaże się z bardzo słabą zależnościa pomiędzy badanymi zmiennymi, przy czym ta zależność była nieistotna (istotność przybliżona wynosiła 0,270 , i przewyższała wartość graniczną 0,05$)$.

W przypadku młodzieży akademickiej, uczęszczającej na zajęcia drugiego stopnia, udział osób prowadzących w dniu badania i/lub w przeszłości własną działalność gospodarczą kształtował się następująco: 4,1\% studentów pierwszego roku oraz $8,9 \%$ studentów drugiego roku jest lub było przedsiębiorcami. Większy udział osób przedsiębiorczych wśród studentów drugiego roku drugiego stopnia może świadczyć o tym, że lepiej wykształcona młodzież akademicka częściej zakładała własną działalność lub także to, że pod koniec studiów drugiego stopnia, gdy jest z reguły mniej zajęć na uczelni, można poświęcić więcej czasu na założenie i prowadzenie własnej działalności gospodarczej. Jest to o tyle dobre rozwiązanie, że już będąc na studiach, można powoli przygotować się do założenia działalności gospodarczej, a po ich zakończeniu założyć działalność i swobodnie poświęcić się pracy na własny rachunek, nie ryzykując przy tym okresem przejściowym między zakończonym etapem edukacji a poszukiwaniem i rozpoczęciem pracy. Przy czym wartość współczynnika kontyngencji dla tych obserwacji wynosiła 0,098 , a to wyraża bardzo słabą zależność pomiędzy badanymi zmiennymi, ale ta zależność była istotna, gdyż istotność przybliżona stanowiła 0,038 , czyli była niższa niż 0,05 . Co ciekawe, wskaźnik postawy przedsiębiorczej był wyższy u studentów pierwszego roku niż u studentów roku drugiego. Rozbieżność ta może mieć związek z innym niż prowadzenie własnej działalności gospodarczej przejawianiem się postawy przedsiębiorczej studentów pierwszego stopnia, np. przez przedsiębiorczość społeczna.

W odniesieniu do studentów studiów jednolitych magisterskich, udział osób prowadzących aktualnie i/lub w przeszłości własną działalność gospodarczą kształtował się 
następująco: 6,5\% studentów pierwszego roku; $0 \%$ studentów drugiego roku; 4,3\% studentów trzeciego roku; $6,7 \%$ studentów czwartego roku i 6,7\% studentów piątego roku prowadzi i/lub prowadziło własną działalność gospodarczą. Wartość współczynnika kontyngencji dla tych obserwacji wynosiła 0,075 , co oznacza bardzo słabą zależność pomiędzy badanymi zmiennymi, ale ta zależność była nieistotna, gdyż istotność przybliżona równała się 0,848 , czyli była wyższa niż 0,05 .

Badając przedsiębiorczość młodzieży akademickiej, zapytano również o chęć założenia własnej działalności gospodarczej przez respondentów. Wśród ogółu ankietowanych studentów 18,7\% chciało założyć własną działalność gospodarcza, 21\% nie chciało założyć takiej działalności, a 60,3\% respondentów odpowiedziało, że jeszcze o tym nie myślało [Andrzejczyk, 2016]. Można zatem przyjąć, że u ponad 60\% studentów mógł nie pojawić się wystarczający bodziec do tego, by zastanowili się oni nad założeniem i prowadzeniem własnej działalności gospodarczej. Jest to o tyle pozytywny aspekt, że nie zostali oni jeszcze ani zachęceni, ani zniechęceni. Aby u tych osób pojawiła się zatem myśl, która może przekształcić się następnie w pewność deklaracji założenia własnej działalności gospodarczej, należy podjąć odpowiednie działania, gdyż można zarówno zachęcić młodzież do zostania przedsiębiorca, lub na odwrót, można do tego zniechęcić.

Analizując daną kwestię z uwzględnieniem płci, warto zauważyć, iż 14,5\% kobiet chciało założyć własną działalność, 20,9\% nie chciało założyć własnej działalności gospodarczej, a 64,6\% ankietowanych kobiet jeszcze o tym nie myślała. W przypadku mężczyzn aż 26,1\% respondentów chciało założyć własną działalność gospodarcza, $21,1 \%$ nie chciało założyć własnej działalności, a 52,8\% jeszcze o tym nie myślało [Andrzejczyk, 2016]. Okazuje się więc, że znacznie mniej kobiet niż mężczyzn zarówno prowadzi lub prowadziło własną działalność, jak i chce założyć własną działalność gospodarcza.

W strukturze respondentów z podziałem na tryb studiów udział osób, które chciały założyć własne przedsiębiorstwo, był bardzo zbliżony (dla studentów stacjonarnych $18,62 \%$, niestacjonarnych $18,75 \%$ ), także wśród studentów z pierwszego i drugiego stopnia (kolejno: 19,05\% i 19,82\%) udział takich osób był podobny. Nieco mniejszy udział deklarujących chęć założenia przedsiębiorstwa dostrzeżono w grupie respondentów będących na studiach jednolitych magisterskich (14,4\%) [Andrzejczyk, 2016]. Wydaje się to o tyle zaskakujące, że większość kierunków studiów nauczanych na studiach jednolitych magisterskich dosyć silnie kojarzy się z własną działalnościa gospodarczą (np.: prawnicy, lekarze, dentyści zakładający prywatne poradnie czy gabinety).

\section{Podsumowanie}

W niniejszym opracowaniu przedstawiono część wyników z badań przeprowadzonych przez autorkę, dotycząca przedsiębiorczości młodzieży akademickiej województwa podlaskiego. Skupiono uwagę na tym, czy respondent wykazuje postawę przedsiębiorczą i w jakim stopniu, czy prowadzi lub prowadził własną działalność gospodarczą lub przejawia chęć założenia własnej działalności. 
Studentów objętych badaniem charakteryzował średni stopień przedsiębiorczości. Postawa przedsiębiorcza w poszczególnych, analizowanych grupach studentów odzwierciedlała inną wartość WSKP. Najwyższa wartość ogólnego wskaźnika przedsiębiorczości obejmowała grupę studentów będących na studiach niestacjonarnych, następnie studentów studiujących na uczelniach prywatnych, zaś najniższa studentów studiów stacjonarnych oraz niektóre roczniki poszczególnych studiów.

Równocześnie w badaniu analizowano trzy najsilniejsze i trzy najsłabsze składniki cząstkowe ogólnego wskaźnika przedsiębiorczości. We wszystkich badanych grupach najsilniejszym składnikiem cząstkowym wskaźnika postaw przedsiębiorczych była umiejętność brania odpowiedzialności za podejmowane działania, natomiast kolejne z najwyższych wartości składowych to: podejmowanie działań w zakresie rozwoju osobistego i ciężka praca, by osiagnąć wyznaczony cel. Wysokie wartości przyjmowały zarazem: łatwość $\mathrm{w}$ nawiązywaniu kontaktu $\mathrm{z}$ innymi ludźmi, posiadanie wielu pomysłów, które chciałoby się zrealizować, oraz umiejętności organizacyjnych.

Najniższe wartości wśród składników wskaźnika postaw przedsiębiorczości w badanych grupach najczęściej należały do następujących: „Lubię przejmować inicjatywę w realizowanych przedsięwzięciach”, „Uważam, że jestem przedsiębiorcza/przedsiębiorczy”, „W trudnych sytuacjach jestem opanowana/opanowany”. Jednocześnie nisko zostały ocenione: „Chętnie angażuje się w nowe przedsięwzięcia”, „Pojawiające się problemy traktuje jako wyzwania”, „Łatwo dostosowuję się do zmian zachodzących w moim otoczeniu” i „Nie boje się nietypowych rozwiązań".

Niewielki udział studentów podlaskich uczelni w dniu badania prowadzi lub prowadziło własną działalność gospodarcza. Najwyższy udział studentów przedsiębiorczych w wymiarze prowadzenia w dniu badania i/lub w przeszłości działalności gospodarczej był w grupie studentów uczelni niepublicznych i studentów studiów niestacjonarnych, co potwierdziły także najwyższe wskaźniki ogólne postawy przedsiębiorczej wśród studentów studiów zaocznych i uczelni prywatnych spośród wszystkich badanych grup.

Zastanawiające może być to, że wśród ogółu ankietowanych studentów większość jeszcze nie myślała o tym, czy chce założyć własną działalność gospodarczą. U tych studentów mógł zatem nie pojawić się wystarczający bodziec do tego, aby zastanowili się oni nad założeniem i prowadzeniem własnej działalności gospodarczej. Jest to o tyle pozytywny wniosek, że prawdopodobnie studenci ci nie zostali jeszcze ani zachęceni, ani zniechęceni do założenia własnej działalności gospodarczej. Natomiast, analizując daną kwestię z uwzględnieniem płci, należy stwierdzić, iż znacznie mniej kobiet niż mężczyzn prowadzi lub prowadziło własną działalność oraz chce założyć własną działalność gospodarczą.

\section{Literatura}

Andrzejczyk A., 2016, Wphyw edukacji na roswój przedsiębiorçości. Raport z badań, Polskie Towarzystwo Ekonomczne, Oddział w Białymstoku, Białystok.

Aronson E., Wilson T. D., Akert R. M., 1997, Psychologia spoteczna - serce i umyst, Wydawnictwo Zysk i S-ka, Poznań. 
Brownlow L., Semple Sh., Howieson C., McKechnie J., 2004, Measuring Enterprising Skills and Attitudes: a Review, http://www.ces.ed.ac.uk/PDF\%20Files/PTW_WP2.pdf (data wejścia: 9.09.2015).

Czerwiński K., 2007, Metodologiczne aspekty pomiaru postaw jako mypadkowej systemu wartości, [w:] Komunikacja spoteczna a wartości w edukacij. Nowe znaczenie i sytuacje. Humanistyczne (i inne) konteksty komunikowania , sie" $i$, Ja" w obszarze wartości wewnatrzedukacji, W. J. Maliszewski (red.), Wydawnictwo Adam Marszałek, Toruń

Edukacja w z̧akeresie prz̨edsiębiorczości. Doświadczenia Polski i Hisæpanii, 2014, M. Kokocińska, H. Nowak (red.), Wydawnictwo Difin, Warszawa.

Frankfort-Nachmias C., Nachmias D., 2001, Metody badawcze w naukach spotecznych, Wydawnictwo Zysk i S-ka, Poznań.

Gaweł A., Pietrzykowski M., 2015, Edukacja akademicka w postrzeganiu przedsiębiorczósci i ksztaltowaniu intenciji przedsiębiorcsych, „Problemy Zarządzania”, vol. 13, nr 1 (51), t. 2, Przedsiębiorczość w XXI wieku: oblicza i wyzwania.

Gibson S. G., Harris M. L., Mick T. D., Burkhalter T.M., 2011, Comparing the Entrepreneurial Attitudes of University and Community College Students, „Journal of Higher Education Theory and Practice", vol. 11(2).

Grzegorzewska-Mischka E., 2010, Wspótczesne unarunkowania rozwoju przedsiębiorczości w Polsce, Oficyna Wydawnicza Szkoły Głównej Handlowej w Warszawie, Warszawa.

Grzegorzewska-Mischka E., Wyrzykowski W., 2009, Przedsiebiorczość, pržedsiebiorca, przeedsiebiorstwo, Bookmarket, Gdańsk.

Haber L. H., 2011, Postany prz̨edsiebiorcze w retrospektywie transformacji społecznej w kierunku kapitalizmu. Kontynuacja, [w:] Præ̌emiany pracy, postaw i ról zawodonych, D. WalczakDuraj (red.), Wydawnictwo Uniwersytetu Lódzkiego, Lódź.

Nowak H., 2014, Dyskusja nad rola edukacji w rozwoju przedsiębiorczości, [w:] Edukacja w zakeresie przedsiębiorczości. Doświadczenia Polski i Hiszpanii, M. Kokocińska, H. Nowak (red.), Wydawnictwo Difin, Warszawa.

Oppenheim N., 2004, Kwestionariusze, mywiady, pomiary postaw, Wydawnictwo Zysk i S-ka, Poznań.

Piecuch T., 2010, Przedsiebiorczość. Podstawy teoretyczne, Wydawnictwo C.H. Beck, Warszawa.

Rachwał T., Wach K., 2016, Badanie intencji przedsiebiorczych mtodego pokolenia: wyniki ankietyzacji wśród studentón kierunków nieekonomicznych, Przedsiębiorczość - Edukacja, vol. 12.

Rathus S. A., 2004, Psychologia wspótczesna, Gdańskie Wydawnictwo Pedagogiczne, Gdańsk.

Ustawa ₹.dnia 2 lipca 2004 roku o swobodzie działalności gospodarczej, Dz. U. 2004, Nr 173, poz. 1807.

Węcławska D., 2013, Charakterystyka pręedsiebiorcón w Polsce na podstawie danych Labour Force Survey, [w:] Raport o stanie sektora matych i średnich przedsięiorstw w Polsce w latach 2011-2012, Polska Agencja Rozwoju Przedsiębiorczości, Warszawa, http://www.parp.gov.pl/files/74/81/626/18670.pdf (data wejścia: 9.09.2015). 
Węcławska D., Zadura-Lichota P., 2010, Wpływ edukacji na postawy przedsiębiorcze i przygotowanie młodych Polaków do prowadzenia driałalności gospodarczej, [w:] Raport o stanie sektora malych $i$ średnich przedsiebiorstw w Polsce w latach 2008-2009, Polska Agencja Rozwoju Przedsiębiorczości, Warszawa, http://www.parp.gov.pl/files/74/81/ 380/9282.pdf (data wejścia: 9.09.2015). 